INTERNATIONAL MONETARY FUND
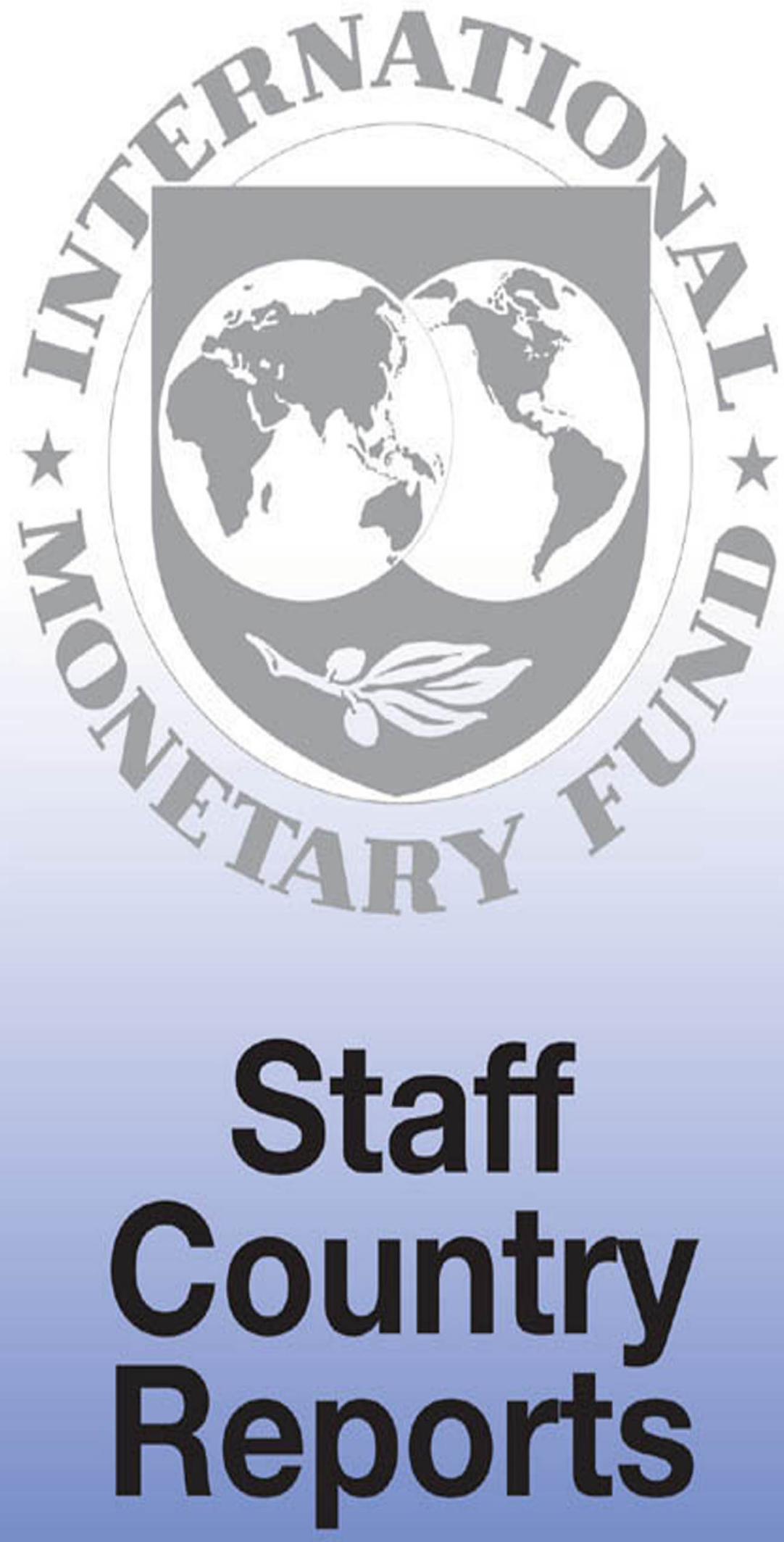


\section{Former Yugoslav Republic of Macedonia: Selected Issues}

This Selected Issues paper for the Former Yugoslav Republic of Macedonia was prepared by a staff team of the International Monetary Fund as background documentation for the periodic consultation with the member country. It is based on the information available at the time it was completed on May 16, 2012. The views expressed in this document are those of the staff team and do not necessarily reflect the views of the government of the Former Yugoslav Republic of Macedonia or the Executive Board of the IMF.

The policy of publication of staff reports and other documents by the IMF allows for the deletion of market-sensitive information.

Copies of this report are available to the public from

International Monetary Fund • Publication Services

700 19th Street, N.W. • Washington, D.C. 20431

Telephone: (202) 623-7430 • Telefax: (202) 623-7201

E-mail: publications@imf.org • Internet: http://www.imf.org

\section{International Monetary Fund Washington, D.C.}


This page intentionally left blank

CInternational Monetary Fund. Not for Redistribution 


\section{INTERNATIONAL MONETARY FUND \\ FORMER YUGOSLAV REPUBLIC OF MACEDONIA}

\section{Selected Issues}

Prepared by Maral Shamloo, Eugen Tereanu, Alexander Tieman (all EUR), Nicolas Arregui (MCM), Ran Bi (SPR),

Approved by the European Department

May 16, 2012

Contents

I. Debt Market Development in FYR Macedonia.

A. Introduction .2

Market Evolution

Current Market Structure and Investor Base

Regional Comparison

B. Going Forward: Further Market Development and Risk Mitigation

Market Development

Risk Mitigation

References

II. Euroization in FYR Macedonia: Causes and Policies Implications .15

A. Introduction .15

B. Causes of Loan Euroization $\frac{16}{16}$

Main Causes Identified in the Literature .16

Assessing Loan Euroization in FYR Macedonia ………………………….... 18

C. Policy Implications for FYR Macedonia $\frac{19}{22}$

D. Conclusions

References .$\underline{24}$

III. Autonomy of Monetary Policy under a Peg: The case of FYR Macedonia

A. Introduction .$\underline{25}$

B. The Policy Rate in 2000-2011 . .25

C. The Degree of Monetary Autonomy . .26

D. A Model of Semi-Autonomous Monetary Policy .28

A Simplified Model .$\underline{29}$

E. Conclusions 


\section{DEbT MARKet DeVelopment in FYR MACEDOnia}

\section{A. Introduction ${ }^{1}$}

\section{This paper assesses Macedonia's public debt markets and presents} recommendations for their further development. Domestic market development will diversify funding sources and reduce reliance on volatile external financing, providing a more stable base for fiscal financing. Increased liquidity and depth of the domestic market will allow for better management of risks. Establishing a reference yield curve will generate positive externalities for the private sector. Market development requires a medium-term comprehensive strategy, and involves many incremental steps.

\section{Macedonia's domestic debt market is in the early stages of development, and it} is small by regional standards. Most debt remains is external, to multilateral creditors. Domestic debt market development started only in 2004, when the first paper for regular market financing was issued domestically. This was followed by Macedonia's first Eurobond in 2005. Market development was interrupted by the financial crisis, when risk appetite for longer-term issues diminished and the authorities, in the face of budgetary pressure, started to issue only at short maturities to minimize costs. Today, the domestic market remains shallow, with some 5 percent of GDP in regular bills and bonds outstanding, almost all at short maturities (Figure 1). Private external financing represents an additional 6 percent of GDP. ${ }^{2}$

\begin{tabular}{|c|c|}
\hline & Box 1. Main Recommendations on Market Development \\
\hline$\bullet$ & $\begin{array}{l}\text { Increase the size of the domestic government debt market to reduce reliance on } \\
\text { volatile external funding. }\end{array}$ \\
\hline - & Lengthen domestic maturities, and be prepared to pay market interest rates. \\
\hline$\bullet$ & $\begin{array}{l}\text { Enhance liquidity through fungibility and attention to secondary market } \\
\text { development. }\end{array}$ \\
\hline$\bullet$ & Measure risks explicitly and benchmarks them against a chosen debt profile. \\
\hline$\bullet$ & $\begin{array}{l}\text { Reduce refinancing risk through pre-financing and avoiding bunching of } \\
\text { maturities. }\end{array}$ \\
\hline • & Further develop institutions and practices to achieve these goals. \\
\hline
\end{tabular}

\footnotetext{
${ }^{1}$ Prepared by Eugen Tereanu, etereanu@imf.org, and Alexander Tieman, Resident Representative, atieman@imf.org. This work has benefitted from discussion with many stakeholders in Macedonia, as well as comments from Wes McGrew and Guilherme Pedras. The authors would like to thank them all.

${ }^{2}$ Debt statistics are based on data through 2011 Q4.
} 


\section{Market Evolution}

\section{The process of developing the government securities market in Macedonia} started in earnest in 2004-05. Prior to that, Macedonian domestic debt consisted exclusively of special purpose (structural) bonds, which were issued to compensate people for transition-related losses. In 2004, the first (domestic) treasury bills for regular budget financing were issued. The next year, the first Eurobond was issued.

4. The domestic curve was gradually built up. Initial issuance was limited to 3 months treasury bills but in 2005 the authorities began issuing longer maturities. By 2007, the yield curve consisted of mainly 3, 6 and 12 month bills but also included modest volumes of 2, 3 and 5-year treasury bonds. Public debt included treasury bills issued with the specific purpose of mopping up excess liquidity in the banking system. ${ }^{3}$ The building up of the curve was supported by sustained communication with markets and stakeholders, including a comprehensive three-year rolling medium term debt strategy, regular market reports and a predictable auction calendar.

5. Macedonia tapped the external private market just three times. Most of Macedonia's external debt remains with multilateral lenders. A ten-year $€ 150$ million Eurobond was issued in 2005, followed by a three and a half year $€ 175$ million Eurobond in 2009. A planned Eurobond issue was cancelled in 2010, due to the turmoil in international financial markets following the run-up to the first Greek program. In December 2011, the government procured a 5-year $€ 130$ million syndicated loan, which was supported by a Policy-Based Guarantee from the World Bank.
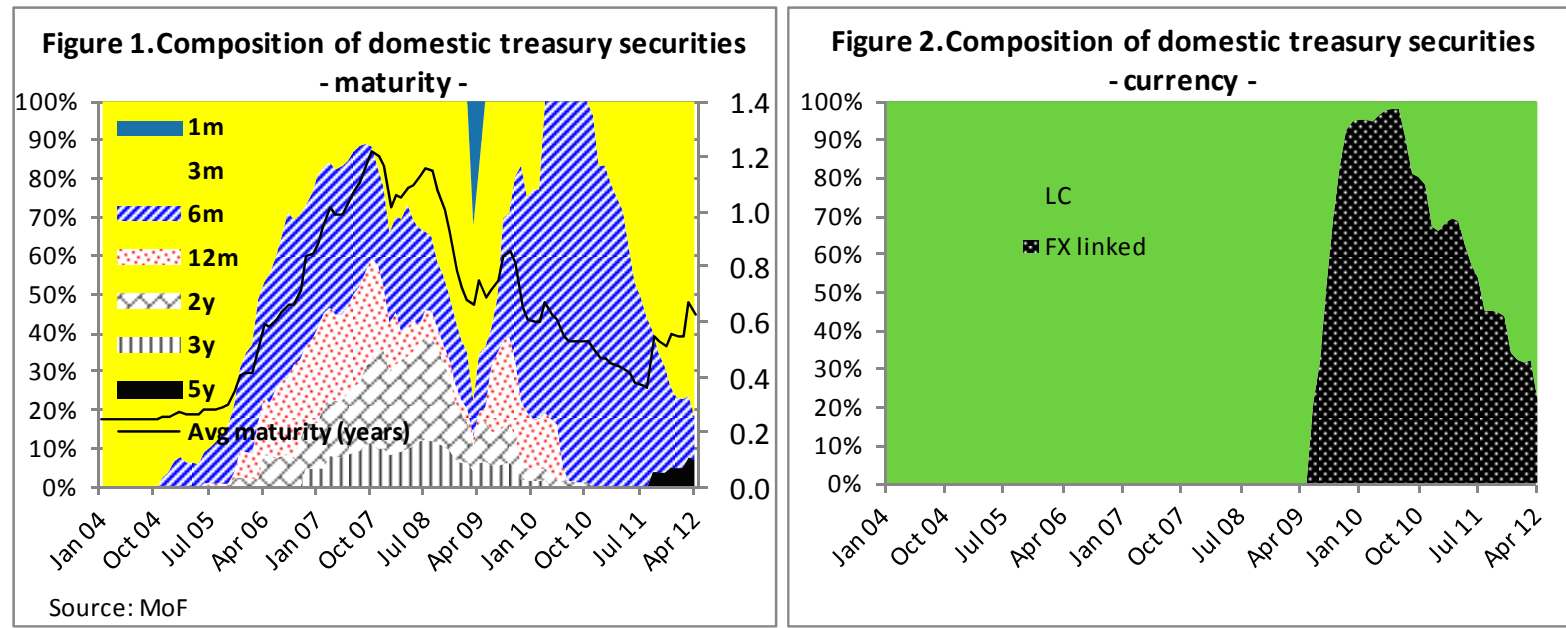

\footnotetext{
${ }^{3}$ This paper was explicitly labeled as "T-bills for monetary policy purposes", and its issuance was coordinated with the National Bank (NBRM). As, in the absence of the issuance of these T-bills, the NBRM would have had to mop up this liquidity using central bank bills, the NBRM agreed with the MoF to compensate the MoF for the interest payments on these bills.
} 


\section{The global economic crisis in $\mathbf{2 0 0 9}$ and related budgetary pressures}

side-tracked attention for domestic market development. Interest cost savings prompted the government to concentrate issuance on the 3- and 6-month segments, and switch from interest rate to volume tenders to keep full control over interest rates. In addition, the Ministry of Finance (MoF) introduced 3- and 6-month euro-linked, denar-denominated securities, which temporarily replaced denar issues. As a result, the average maturity of outstanding debt shortened considerably (Figures 1-2). Initially, the premium of local currency over FX-index debt was some 400 basis points, reflecting significant cost savings for the government. As domestic interest rates came down on the back of lower risk premia and monetary easing, the spread diminished and now stands at just 10 bps (Figure 3). From end-2010 when denar T-bill issuance recommenced, the interest rate on local currency T-bills was set at a spread of 20-30 bps over the central bank's 30-day policy rate.

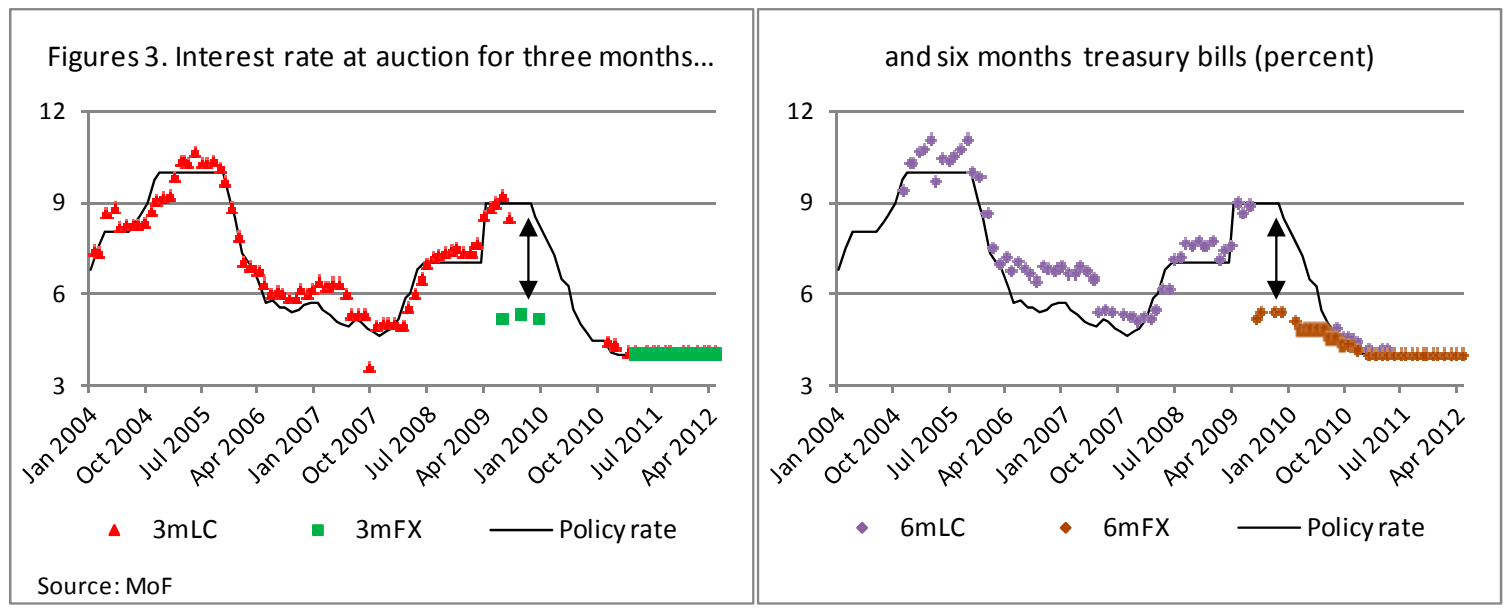

\section{Current Market Structure and Investor Base}

\section{Macedonia's general government debt amounts to some $€ 2$ billion or} 28 percent of GDP, almost three quarters of which is external (Figure 4). Total external debt amounts to $€ 1.6$ billion, with close to 60 percent coming from multilateral creditors (Figure 5). The two outstanding Eurobonds represent about 21 percent of general government external debt. Domestic government securities add up to some $€ 507$ million equivalent, including $€ 355$ million in regular bills and bonds ("marketable securities"). The remaining $€ 150$ million consists of structural bonds, which were issued to compensate people for transition-related losses, and are almost all at fixed rates. Within the group of marketable securities, short-term treasury bills make up some 95 percent (Figure 7), with the remaining 5 percent representing recently issued 5-year treasury bonds. Almost 50 percent of domestic government securities is indexed to or denominated in euros. 


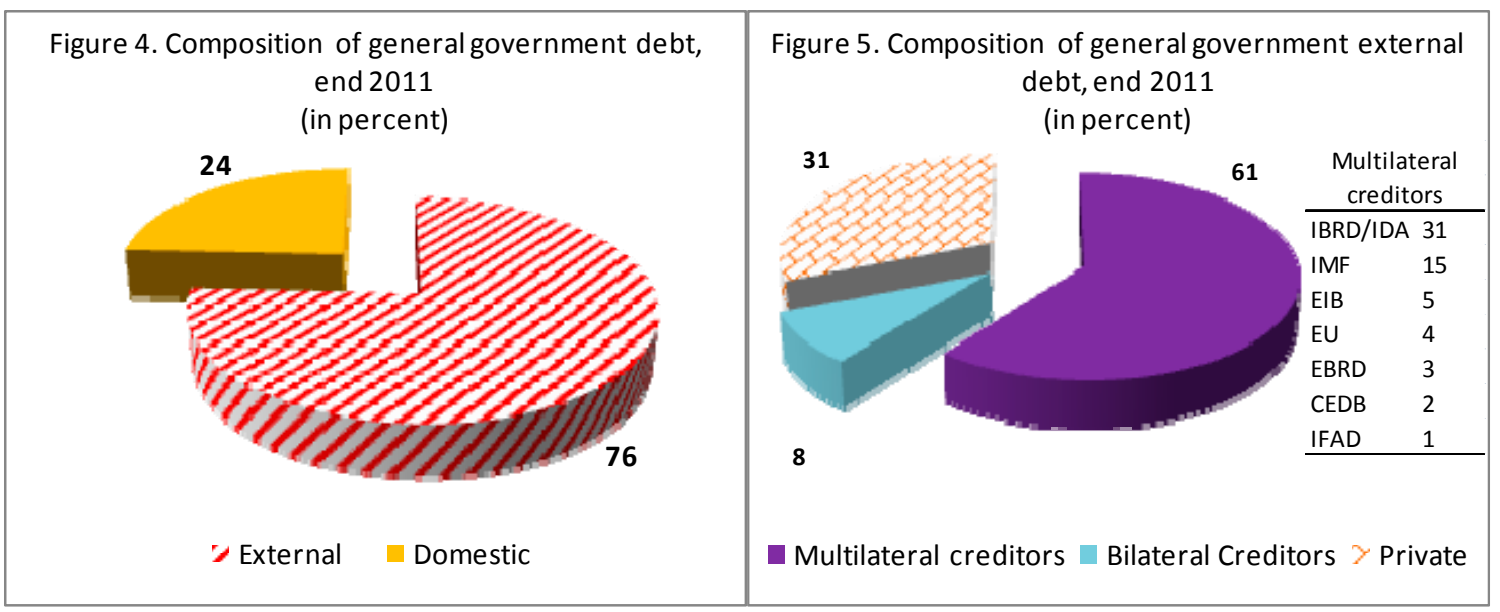

8. Banks are by far the largest investor category in the domestic market, holding almost two-thirds of regular government securities (Figure 6). The second largest category comprises "other" investors, which includes the Deposit Insurance Fund (DIF), private companies and individuals. Pension funds and life insurance companies currently hold small slices of the market, but represent promising investor categories in the medium-term. Second-pillar (mandatory, private) pension funds are in the build-up phase, and as such have a rapidly growing asset base of some $€ 250$ million at end-2011. A significant share of their assets is invested in Macedonian Eurobonds, mostly bought on the secondary market. In addition, recent 5-year domestic bond issuances were largely bought by the pension funds. The insurance sector has total assets of some $€ 210$ million, but is only a modest investor in government paper, holding some $€ 15$ million in domestic government securities. Life insurance assets comprise less than $€ 30$ million and are growing at a 15 percent annual rate. Life companies currently invest some 40 percent of assets in government securities, both domestic and Eurobonds. Despite the absence of regulatory barriers to foreign investors, they do not hold domestic government debt. They likely see the market as too small and shallow, and can get exposure to Macedonia by buying Eurobonds rather than domestic paper.

$\begin{gathered}\text { Figure 6. Ownership structure of domestic } \\ \text { treasury bills and bonds (in percent) 1/ }\end{gathered}$
$\begin{aligned} & \text { Figure 7. Composition of general government } \\ & \text { domestic debt, end } 2011 \\ & \text { (in percent) }\end{aligned}$
Insurance companies $\quad \begin{aligned} & 30 \text { of which } 11 \% \text { denar } \\ & \text { 1/Data of November 2011. "Other" includes the deposit insurance } \\ & \text { fund, private companies and individuals. }\end{aligned}$




\section{Regional Comparison}

9. Macedonia's government debt ratio has decreased substantially over the last decade and is modest by regional standards. Between 2000 and 2010 , government debt halved from over one-half to close to one-quarter of GDP (Figure 8). The decrease was most marked in the early part of the decade, but continued until 2008. In contrast with most of its regional peers, Macedonia had lower government debt as a share of GDP in 2010 than in 2006, before the crisis, and the current debt level is among the lower ones in the region (Figure 9, top left).

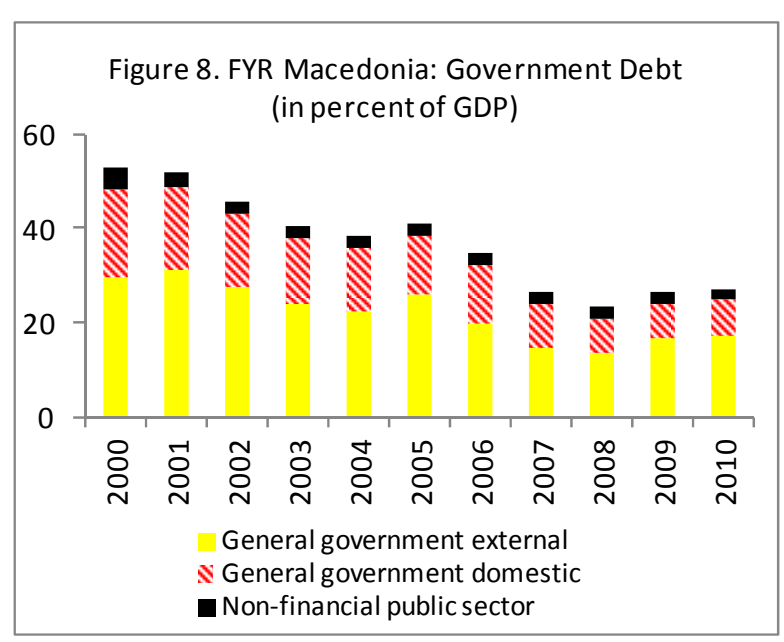

10. Almost all regional peers have a larger domestic debt market, featuring longer maturities (Figure 9). At the end of 2010, Macedonia's domestic debt was just under 8 percent of GDP, among the lowest in the region. Macedonia also stands out among comparator countries in terms of the maturity structure of domestic debt, which is almost completely concentrated on the short end of the yield curve. In contrast, most regional peers feature short-term debt of less than half of total, and many have increased average maturity over time.

\section{Debt strategy formulation is broadly in line with regional peers but has}

regressed somewhat over the last few years. Macedonia's debt management strategy covers a period of 3 years, a horizon comparable to that of its peers (Table 1). However, on operational risk benchmarks, Macedonia's strategy covers only currency composition, while most countries in the region cover maturity, variability and duration as well. In addition, since 2009 Macedonia has not published an ex-post evaluation of its strategy, the publication of which is generally seen as best-practice.

Table 1. Debt strategy implementation in CESEE 1/

\begin{tabular}{|c|c|c|c|c|}
\hline & $\begin{array}{c}\text { Debt } \\
\text { strategy } \\
\text { horizon }\end{array}$ & $\begin{array}{c}\text { Stress } \\
\text { te sts }\end{array}$ & $\begin{array}{l}\text { Operational targets for risk } \\
\text { indicators }\end{array}$ & $\begin{array}{l}\text { Previous strategy } \\
\text { evaluation }\end{array}$ \\
\hline Albania & 3 year & Yes & C.ırrency/maturity/duration & N/A \\
\hline Bulgaria & 3 year & No & Currency/variabi ity & Yes \\
\hline Croatia & 1 year & No & Currency/maturty & N/A \\
\hline Czech Republic & 3 year & Yes & Currency/maturity/variability & N/A \\
\hline Macedonia & 3 year & Yes & Currency & Notcurrently $2 /$ \\
\hline Poland & 4 year & No & Currency/maturity/variability & Yes \\
\hline Romania & 3 year & Yes & Currency/maturity/variability & Yes \\
\hline Slovakia & 3 year & No & C.urrency/maturity/duration & $\mathrm{N} / \mathrm{A}$ \\
\hline \multicolumn{5}{|l|}{ Note: } \\
\hline \multicolumn{5}{|c|}{$\begin{array}{l}\text { 1/Information sourced from the latest publicly available debt strategy or annual borrowing plan; } \\
\text { N/A reflecls that iriumaliun was nul available. }\end{array}$} \\
\hline
\end{tabular}


Figure 9. Central government debt in CESEE, 2006 and 2010
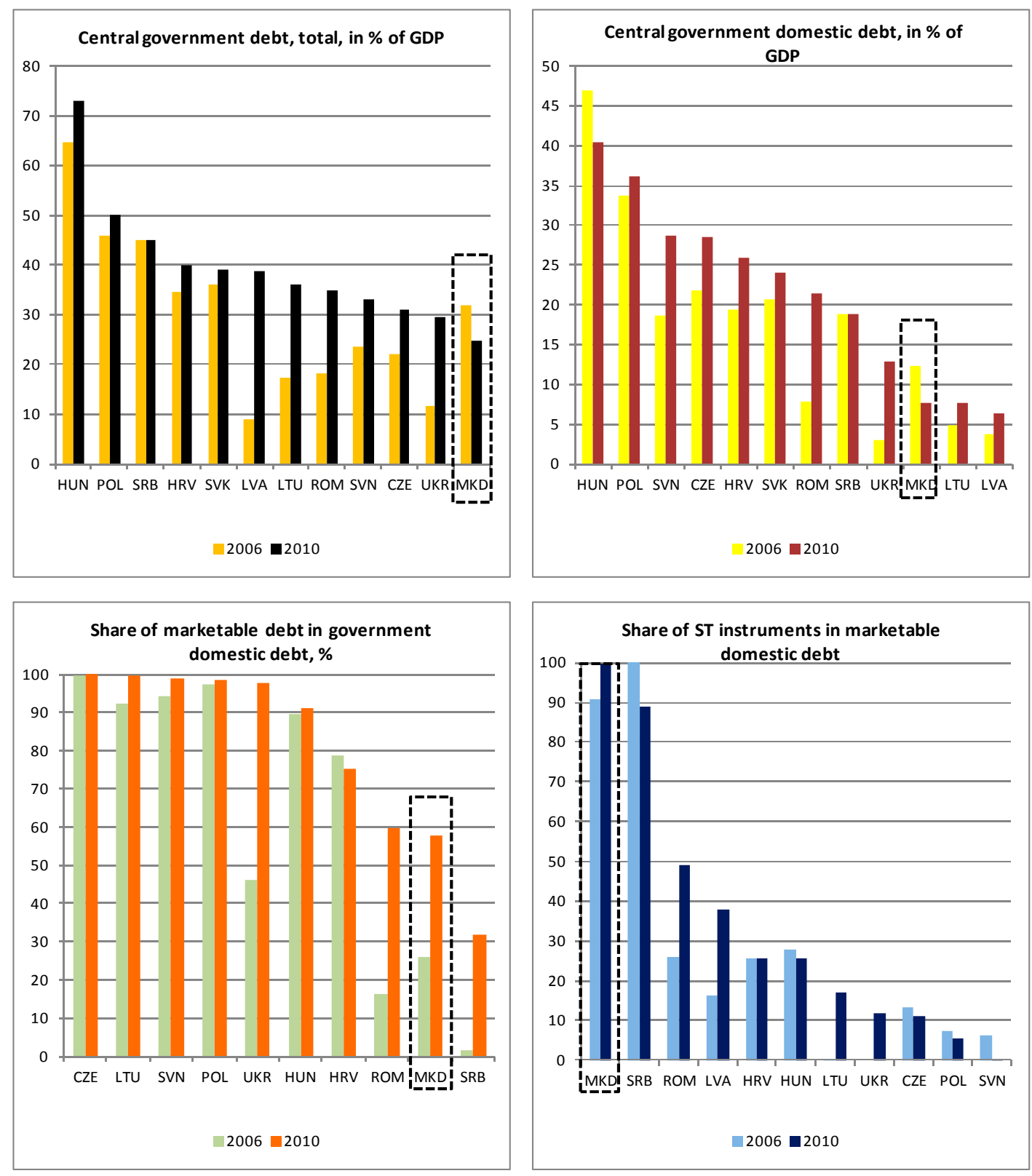

B. Going Forward: Further Market Development and Risk Mitigation

\section{Market Development}

\section{Market development will yield important benefits in the medium run,} including a broader base for fiscal financing and positive externalities for the wider economy. Market development includes deeper and more liquid markets with a longer and better defined yield curve. A liquid market allows investors to offload positions without influencing prices significantly, thus lowering the risk of investing and contributing to lower yields. Greater liquidity should reduce interest rate volatility, leading to additional benefits for both lenders (lower market risk) and borrowers (lower interest and refinancing 
risk). A more developed benchmark yield curve that can be used as a reference by the private sector will also help to stimulate private debt markets.

\section{Market development can be stimulated in several ways.}

- $\quad$ First, Macedonia should use interest rate tenders to provide for price discovery and meet cash management needs. The current practice is to set the interest rate at a certain level (which tends to be left unchanged for extended periods) and allow volume to adjust. This frequently results in undersubscribed auctions, which impedes price discovery and makes it more difficult to meet Treasury cash management objectives (Figures 10-11).

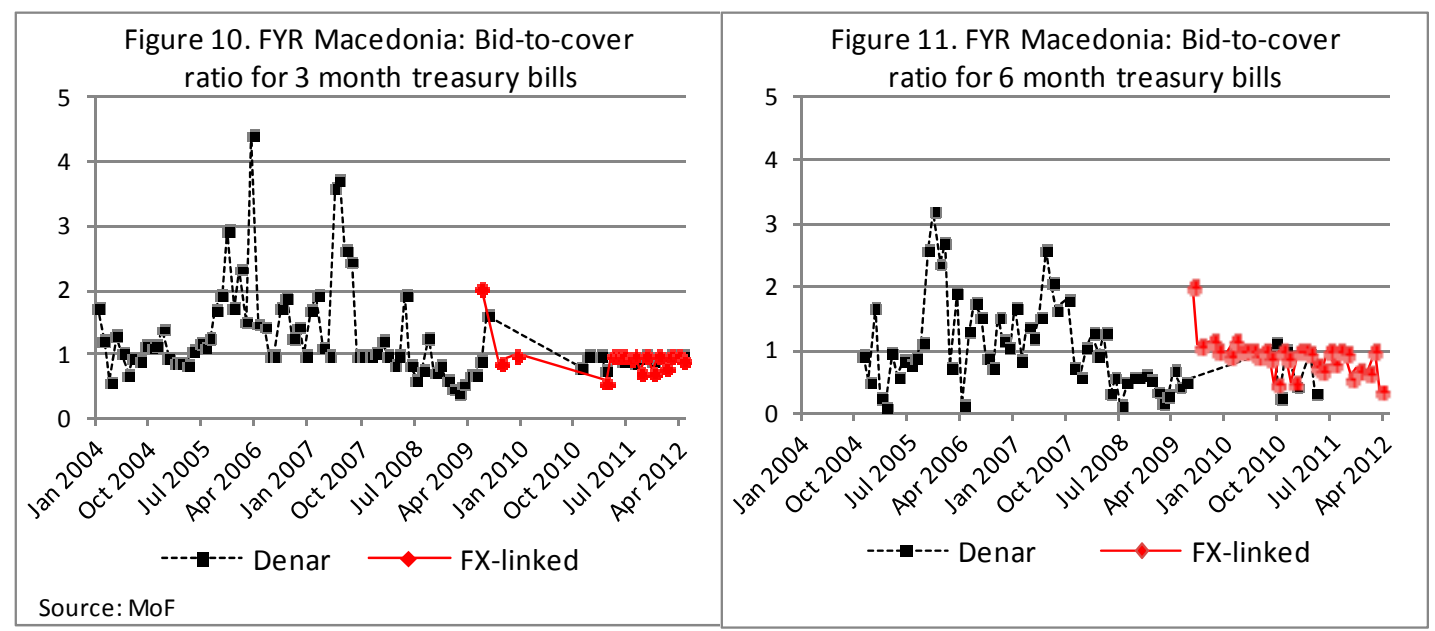

- Second, development of the secondary market would provide investors with some assurances with respect to the presence of market liquidity. Secondary market development can be stimulated by facilitating development of the repo market, concentrating issuance on a limited number of large benchmark issues, and reopening outstanding issues when they reach the next benchmark maturity rather than issuing new securities ${ }^{4}$. In April 2012 the NBRM established a repurchase facility whereby banks could obtain liquidity against holdings of Treasury and central bank securities, which should increase demand for Treasury debt by reducing illiquidity risk.

- Third, to create stable demand, issuance should be predictable, which can be achieved by adhering to a regular calendar of issuance.

- $\quad$ Taken together, these measures would gradually raise the absorption capacity of the domestic market. Box 2 presents the example of the way debt markets developed in Hungary over the years 1998-2008.

\footnotetext{
${ }^{4}$ At the end March 2012 auction of five year domestic bonds, the Ministry of Finance re-opened the December 2011 five year domestic currency issue.
} 


\section{Box 2. Developing Debt Markets in Hungary, 1988-2008}

Hungary's experience is seen as proof that small countries can achieve considerable development of government securities markets if supported by a strong commitment by policymakers. The main lesson is that secondary market development can be greatly expedited by a consistent and integrated approach to market building.

Hungary started to issue treasury bills in 1988. It took eight years to extend the maturity of fixed-rate securities beyond a year. These years were characterized by negligible secondary market activity. Until the Hungarian Debt Management Agency (AKK) became fully operational in 1997, the National Bank of Hungary (MNB) acted as an agent for the government and organized the domestic issuance of government securities. In this period, the MNB also played a market-making role in the government securities market.

As of 1996, the authorities extended the yield curve, first by issuing 2- and 3-year bonds. This was followed a year later by a 5-year bond, and three and five years later by a 10-year and a 15-year bond, respectively. They established a primary dealer system in 1996, and officially established the first benchmark security in 1997.

The AKK implemented several measures to increase liquidity and transparency in the market. In the primary market, the AKK gradually standardized debt instruments, in order to reduce fragmentation and increase fungibility. The AKK also auctioned fewer but larger securities series, and gradually increased the share of domestic currency denominated debt to reduce exchange rate risk. To increase transparency, the AKK published annual financing plans and a 6-months auction calendar in advance. For the secondary market, it compiled and published extensive secondary market data, including daily publication on its website of data on yields and transaction volumes. The secondary market received a further boost by the decision in 1996 to allow nonresidents to invest in government securities, a prelude to full market liberalization in 2001.

By 2008, Hungary's primary and secondary market could be considered well-developed among emerging market countries. The main lesson from the experience of Hungary is that none of the five building blocks of market development (debt management, investor base, market infrastructure, regulatory environment, and monetary policy and operations) can be neglected.

Source: Arvai and Heenan, 2008 


\section{There is ample room to begin increasing the size of the domestic debt market,} which will support to goal of market deepening. Currently, there is excess liquidity in the economy, as evidenced by the stock of central bank bills in the amount of some MKD 33 billion, over 7 percent of GDP (Figure 12). This stock suggests that additional domestic debt issuance may be possible without the risk of crowding out bank lending to the private sector. Moreover, higher issuance of Treasury securities would reduce the need for central bank bills, which would relieve the NBRM's balance sheet of

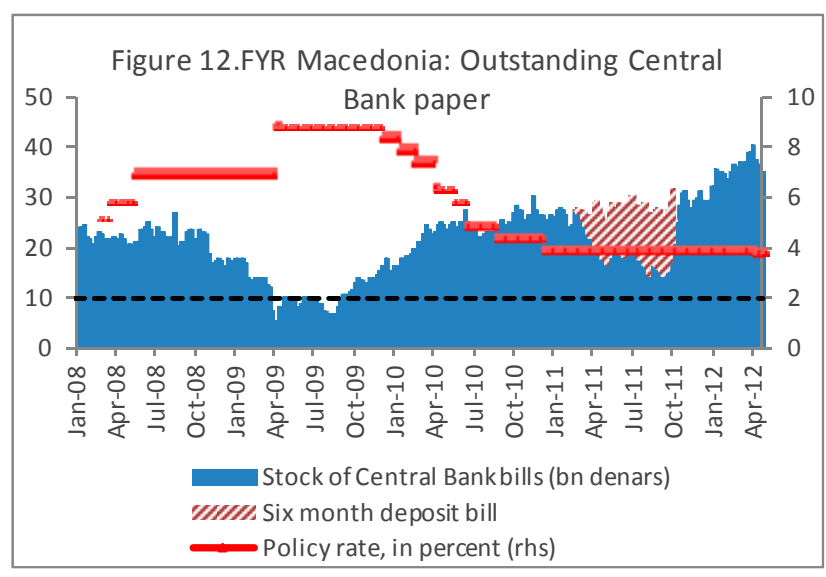
some of the cost of absorbing liquidity.

15. It will take time to increase the size of the domestic debt market. The size of the domestic market is currently modest in relation to forthcoming fiscal financing needs and (domestic and external) debt rollovers. Thus, it will take time to increase the domestic debt market, and external debt will remain an important financing source in the short to medium-term. And even once the domestic debt market is fully developed, external financing will continue to play a role.

\section{Risk Mitigation}

\section{Managing risks and analyzing risk-cost trade-offs are an important aspect of a} medium-term debt strategy. The active management of risks embedded in the debt portfolio should be done in the context of a comprehensive debt strategy that sets risk benchmarks and explicitly captures the tradeoffs between costs and risks. Importantly, as minimizing costs over the medium run may not be consistent with cost minimization in any single year, the strategy should take a medium-term perspective, including with respect to market development. Such a framework allows for thoroughly informed decisions about financing strategies. Specifically, the debt management strategy should explicitly model refinancing, interest rate and currency risks on the current as well as potential alternative public debt portfolio compositions. Performing stress tests of the debt portfolios would allow for such quantification of the risks. Stress tests should include severe, but credible shocks. The magnitude of the shocks can be based on historical experience from either Macedonia or other countries in similar circumstances, or can be of a more discretionary nature. The outcome of the stress tests should be judged against the risk parameters laid out in the debt strategy to see whether risks are acceptable. 
17. Refinancing risk is significant for Macedonia. It will need to repay large Eurobonds maturing in 2013 and 2015, as well as the PLL purchase (in 2014-16) and the bank loan guaranteed by the World Bank PBG (in 2016). Market volatility has been high since the onset of the global crisis, due to external rather than domestic factors. This was evident in 2009, when the government issued a 31/2-year Eurobond at a yield of $97 / 8$ percent, more than double the $45 / 8$ percent yield of the 10 year issuance in 2005, and in 2010 when it canceled a planned Eurobond issuance after market rates spiked in the run-up to the Greek program. In addition, domestic debt features a very short average maturity of just 6 months, and hence the need to roll over existing debt on average

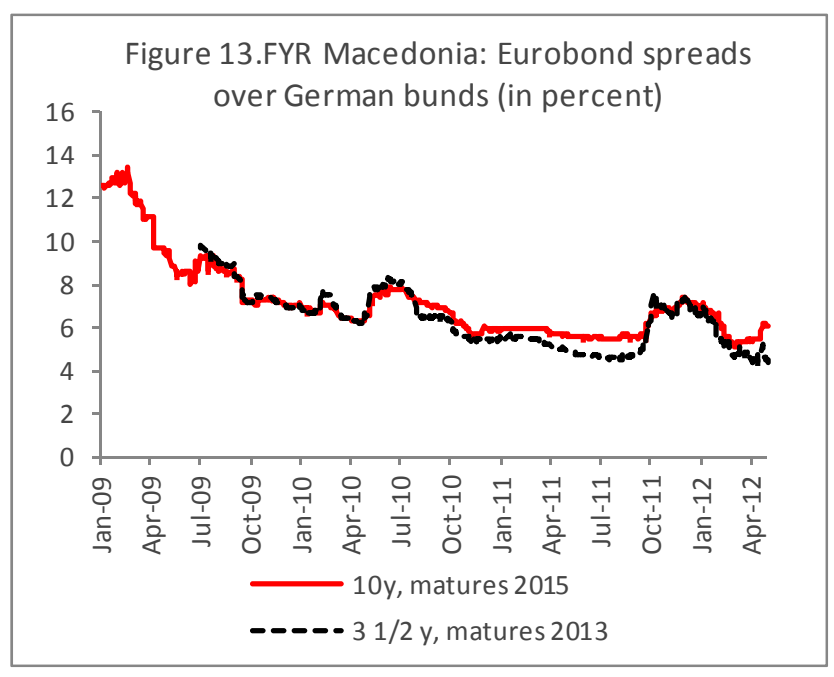
2 times per year (Figure 1).

\section{To mitigate refinancing risk, the government should pre-finance Eurobond} rollovers and lengthen domestic maturities. Given that deepening of the domestic market will only be gradual, the government will need to issue net new private external debt to meet fiscal financing needs, as well as roll over maturing issues. In order to decrease the associated refinancing risk, the authorities should ensure an adequate buffer of deposits by pre-funding rollovers, instead of waiting to issue until shortly before the maturity date of existing debt. The authorities' announcement in April 2012 of a $€ 250$ million loan agreement with a foreign bank is welcome in this regard, as this will pre-finance the $€ 175$ million Eurobond maturing in January 2013. On the domestic side, issuing longer-term paper would increase average maturity and lower refinancing risk. The authorities recently took steps in this direction by initiating a quarterly auction of 5-year bonds starting in September 2011.

\section{Macedonia's exposure to currency risk could} gradually be reduced by increasing domestic non FX-indexed denar issuance. Currency exposure is considerable: all external debt is in FX, and almost half of outstanding domestic government debt is FX-linked (Table 2). Taken together, almost 90 percent of general government debt is hence denominated in or linked to foreign currency. Currency risk - defined as the (high) exposure multiplied by the (low) probability of a

\begin{tabular}{lr}
\multicolumn{2}{c}{$\begin{array}{c}\text { Table 2.Percentage of foreign } \\
\text { currency debt in domestic debt } 1 /\end{array}$} \\
\hline Croatia & 53 \\
Macedonia & 51 \\
Bulgaria & 33 \\
Romania & 26 \\
Serbia & 13 \\
Ukraine & 4 \\
Hungary & 0 \\
Moldova & 0 \\
\hline Note: & \\
1/ Domestic debt denominated in or linked \\
to foreign exchange. Data for Macedonia \\
includes structural bonds.
\end{tabular}

\footnotetext{
${ }^{5}$ In addition, the external private borrowing of $250 \mathrm{mn}$ EUR in the first half of 2012 will mature in 2017.
} 
shock - may not appear to be high in light of the stability of the peg over the past 15 years. However, reducing it would add to policy flexibility in the event of unforeseen shocks in the future. Gradually increasing the share of domestic denar-denominated, non FX-linked debt would be a prudent strategy in this context, together with increasing the share of domestic debt in fiscal financing. These actions would also bring other benefits, including developing the domestic currency yield curve, improving the monetary policy transmission mechanism, and in general promoting greater use of denars in financial transactions.

\section{Market development and well as risk analysis and mitigation should be} supported by strengthening institutional arrangements. Existing arrangements need strengthening along several dimensions (Box 3). The most crucial issue seems to be capacity enhancement for the Ministry of Finance Public Debt Management Department. The department was severely understaffed and it was without a department head for almost 2 years, effectively preventing it from adequately performing its tasks. Recently, under a new decision of the Ministry, the department was merged with the department for EU harmonization and international financial institutions, and a new department head, together with three additional staff, were appointed.

\section{By developing and following a medium-term debt strategy along these lines,} Macedonia can achieve the goal of minimizing medium-term costs subject to keeping risks within appropriate pre-set bounds. As described above, the government has taken the first initial steps toward renewed market development. Further gradual moves in this direction, guided by a comprehensive debt strategy, would bring the goal within reach. Achieving this goal would benefit the budget through lower interest expense and lower risks over the medium term. At the same time, developing a domestic yield curve would yield positive externalities for the real economy, as it would clearly establish a denar yield curve that can be used in pricing private sector loans and bonds. 


\section{Box 3. Institutional Arrangement for Debt Management}

Good institutional arrangements are laid out in Law and regulation. The implementation of these arrangements exhibits gaps, mainly due to severe staff shortages. In addition, communication could be further improved, and information exchange with the NBRM could be formalized.

The Public Debt Law established the responsibilities of the MoF in managing public debt. With the MoF, the Public Debt Management Department (PDMD) is responsible for debt management. It is organized according to best practice in a front, middle, and back office. However, until recently the PDMD had been without a department head for about two years, and the department is still understaffed. In particular, the middle office effectively consists of a single individual, which is not adequate to undertake comprehensive debt management analyses.

Communications with investors are taking place, but more pro-active practices could be introduced. Such practices should include the publication of regular reports on the public debt market, as well as constant contacts with the main stakeholders (among which investors, regulators, financial press, and rating agencies). Front or middle office staff could be assigned with these tasks.

The relationship between debt management and monetary policy has been working well but could be improved further. Specifically, while functionally adequate, the information exchange lacks a formalized structure. A high-level debt management committee could be set up and tasked with coordinating strategy and overseeing implementation. In addition, an operational sub-committee could discuss more granular and technical issues regarding issuance coordination. Liquidity issues are managed through the existing liquidity committee, which meets weekly. This committee could improve its functioning if it could work against the background of a clear definition of the optimal level of cash balances.

Source: IMF, 2011. 


\section{REFERENCES}

Arvai, Zsofia, and Geoffrey Heenan, 2008, “A Framework for Developing Secondary Markets for Government Securities,” IMF Working Paper 08/147, International Monetary Fund, Washington DC.

IMF, 2011, "Developing a Public Debt Management Strategy and Domestic Debt Markets", IMF Technical Assistance Report, International Monetary Fund, Washington DC (not public). 


\section{Euroization in FYR Macedonia: CAuSes ANd Policies IMPlications ${ }^{1}$}

Macedonia is heavily euroized, similar to other emerging markets in the region. This paper analyzes the main causes of euroization in Macedonia, and discusses prospects for and potential benefits of de-euroization. It argues that de-euroization would provide a useful safety valve but other benefits are more limited due to the de facto exchange rate peg to the euro. Based on cross- country experience, Macedonia is likely to remain significantly euroized for an extended period of time. In our view, an appropriate strategy would be to retain incentives and provide a supportive environment for gradual de-euroization by maintaining prudent macro policies, developing domestic debt markets, and maintaining prudential policies that mitigate FX risks, create incentives to de-euroize, and provide buffers in the financial sector.

\section{A. Introduction}

1. The Macedonian economy is highly euroized financially. ${ }^{2}$ Over the last decade, foreign currency (FX) and FX-indexed deposits have accounted for more than 50 percent of total private sector deposits in Macedonia. Loan euroization has increased from around 40 percent at the beginning of the decade to above 55 percent in the last years.

Figure 1. FYR Macedonia: Loan and Deposit Euroization
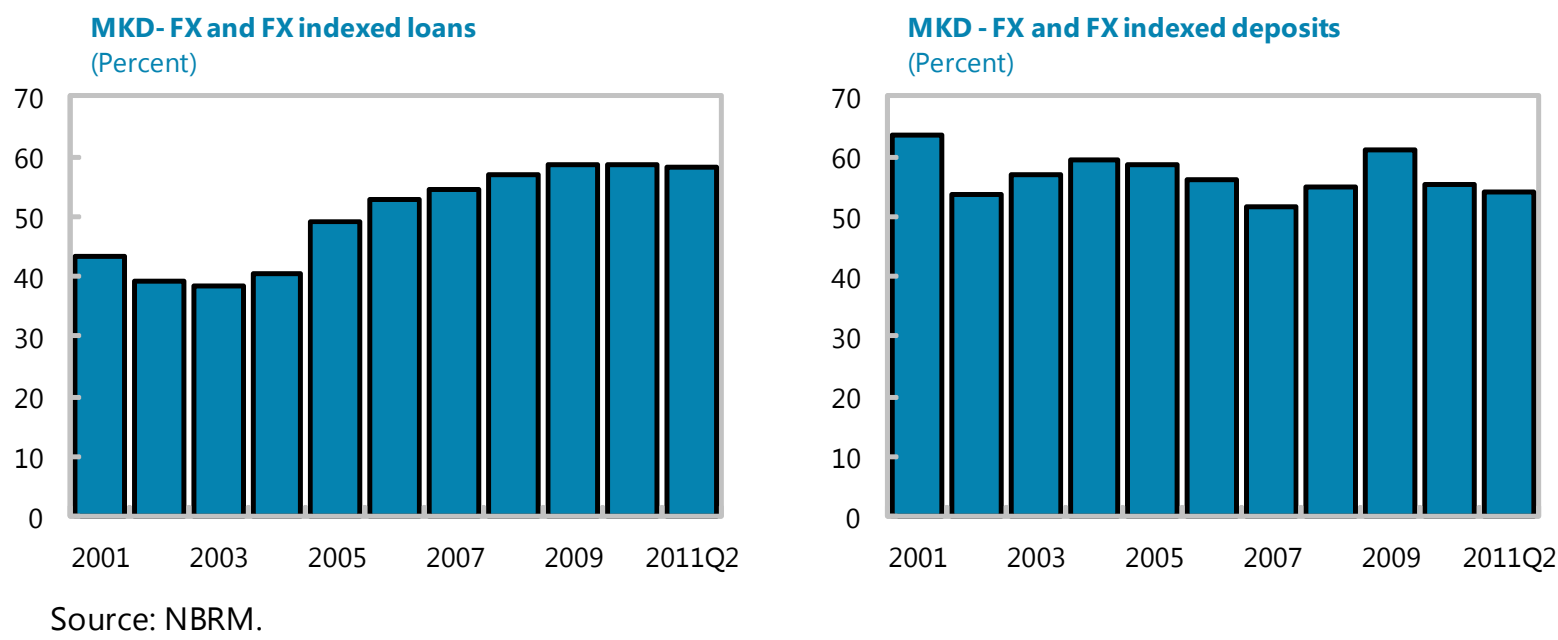

2. High euroization is common in emerging Europe, with countries having fixed exchange rate regimes generally more euroized. Emerging Europe, in general, has a higher

\footnotetext{
${ }^{1}$ Prepared by Nicolas Arregui, narregui@imf.org and Ran Bi, rbi@imf.org.

${ }^{2}$ The term "euroization" denotes the use of any foreign currency, not just euro. Financial euroization is commonly measured as resident financial institutions' holdings of foreign currency denominated assets (loans) or liabilities (deposits) from households and nonfinancial corporations.
} 
degree of euroization (about 60 percent on average) than other regions. For example, FX lending in emerging economies accounts only for 25-30 percent of total loans in Latin America and 5-10 percent in East Asia. Also, countries with fixed exchange rate regimes tend to be more euroized than those with flexible regimes (see Figure 2). In terms of loan euroization, Macedonia is the lowest among pegs, at above 55 percent, for the past few years, slightly below the regional average. In terms of deposit euroization, however, Macedonia is one of the most euroized even among pegs.

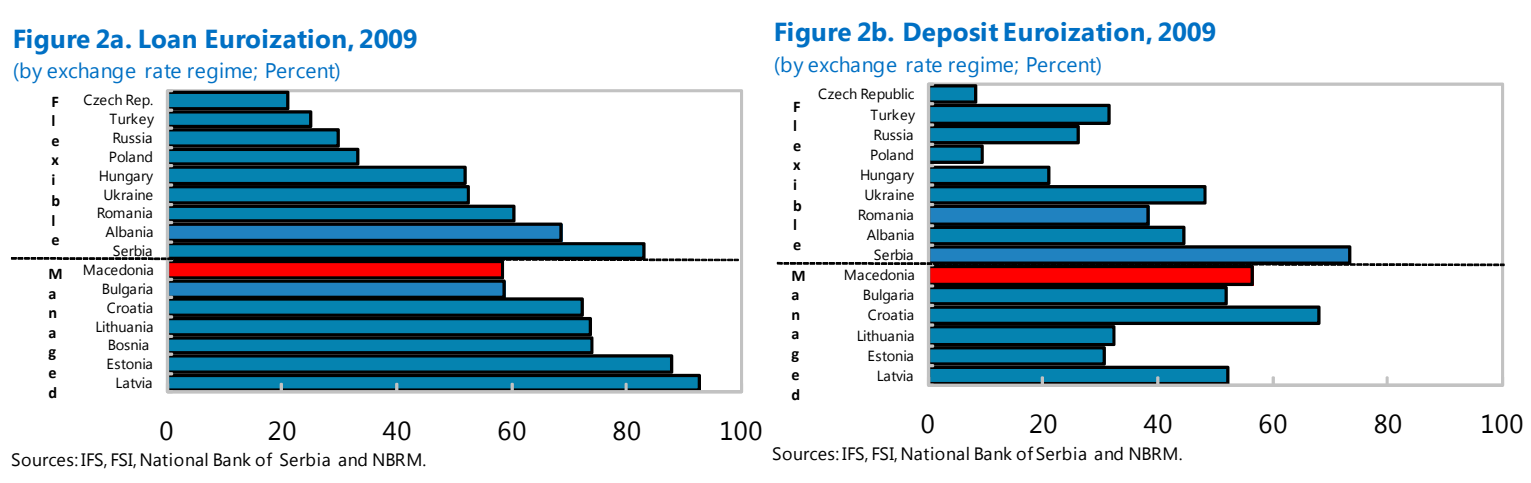

3. A high degree of loan euroization is usually perceived as a policy challenge. As discussed below, euroization poses balance sheet risks to the economy, as borrowers in FX but with income and assets denominated in local currency are vulnerable to sudden shifts in the exchange rate. As a result, currency risk could turn into indirect credit risk. In addition, high euroization reduces the effectiveness of monetary policy transmission as the central bank may affect local currency rates through its policy rate, but has little effect on foreign currency rates.

4. This paper assesses the causes of the high degree of euroization in Macedonia and discusses policy implications, drawing from other countries' experiences. The first section reviews the empirical and theoretical literature on the roots of FX lending. The second section analyzes possible causes for Macedonia. Finally, the last section discusses policy implications for Macedonia, based on the costs and benefits of de-euroization and lessons from cross-country experiences.

\section{B. Causes of Loan Euroization}

\section{Main Causes Identified in the Literature}

5. Empirical studies have found that loan euroization decreases with exchange rate volatility. ${ }^{3}$ The finding holds across exchange rate regimes and within floating regimes. This is in line with what we observe in the SEE region (Figure 2a). Also, inflation volatility tends to be associated with higher levels of FX borrowing. Moreover, loan euroization is lower the

\footnotetext{
${ }^{3}$ See Zettelmeyer, Nagy and Jeffrey (2010) for a survey of the empirical literature on loan euroization.
} 
higher the credibility of macroeconomic policy and institutions, the higher the interest rate differential, the higher the financial development (e.g., credit to GDP) and the higher the foreign (and domestic FX) funding of bank credit.

\section{The multiple root causes of loan euroization identified in the theoretical} literature can be classified into demand and supply-driven causes. Demand side explanations may be grouped in three categories as follows:

- Interest rates on FX-loans are lower than on local currency loans due to devaluation/depreciation risk. Borrowers might not understand, or might underestimate or excessively discount the risks associated with borrowing in FX. In that case, they would opt for the apparent cheapest option, ignoring the risk factor. The outcome is suboptimal both from an individual and social point of view. To address this problem, supervisors in Austria, Hungary, Latvia and Poland, for example, have pushed banks to disclose exchange rate risks to clients, with the assumption that under better information borrowers will reduce their demand for FX loans.

- $\quad$ Borrowing in FX may be an individual and social optimal decision in an environment lacking credible macroeconomic policies or institutions. For example, borrowing in FX could be the less risky strategy in an environment in which inflation is hard to predict. Borrowers commit to a nominal payment in the future (which includes an expected inflation risk premium). Residents' incomes are generally denominated in local currency but adjusted with inflation. When inflation is more volatile than exchange rate fluctuations, borrowing in FX may be preferable as it helps borrowers hedge against inflation risk.

- $\quad$ Residents may choose to borrow in FX because they do not expect to fully bear the costs associated with a depreciation-related insolvency (moral hazard). This would be the case of explicit or implicit government guarantees to borrowers. Moreover, borrowers may not fully internalize the collective benefits of borrowing more in local currency (externality), i.e., when foreign exchange exposures aggravate the risk or severity of a crisis but individual borrowers do not take into account the impact of their decision on collective risks. As a result, euroization could be optimal from an individual point of view but yield a suboptimal social outcome.

\section{On the supply side, banks may price FX loans to make them more attractive} relative to national currency loans to match the currency structures of their assets and liabilities. This could be the result of regulatory requirements or of bank aversion to assume currency risk directly. This explanation is relevant when bank liabilities are biased towards FX (e.g., high euroization in deposits or FX funding from abroad). Rosenberg-Tirpak (2008) and Luca-Petrova (2007) document this finding for new member states of the EU and transition economies, respectively. 


\section{Assessing Loan Euroization in FYR Macedonia}

\section{In this section we review for Macedonia the four possible causes of loan} euroization described in the previous section. We conclude that all explanations contribute to euroization in Macedonia, albeit to different degrees.

\section{Inflation and real exchange rate depreciation volatility appear to play a role}

behind the level of euroization in Macedonia. For emerging Europe, De Haas (2010) finds that higher exchange rate depreciation volatility discourages FX lending and Zettelmeyer-Nagy-Jeffrey (2010) document that FX lending is more prevalent in countries with higher inflation volatility. While the successful exchange rate peg has helped Macedonia attain a low level of inflation, inflation volatility is not low when compared to other countries in the region. Exchange rate volatility, on the other hand, has been low as a result of the peg. Therefore, the rational choice would be to take the smaller risk, i.e., the exchange rate risk, and hence use FX in financial transactions.

\section{Figure 3. Inflation level and volatility.}
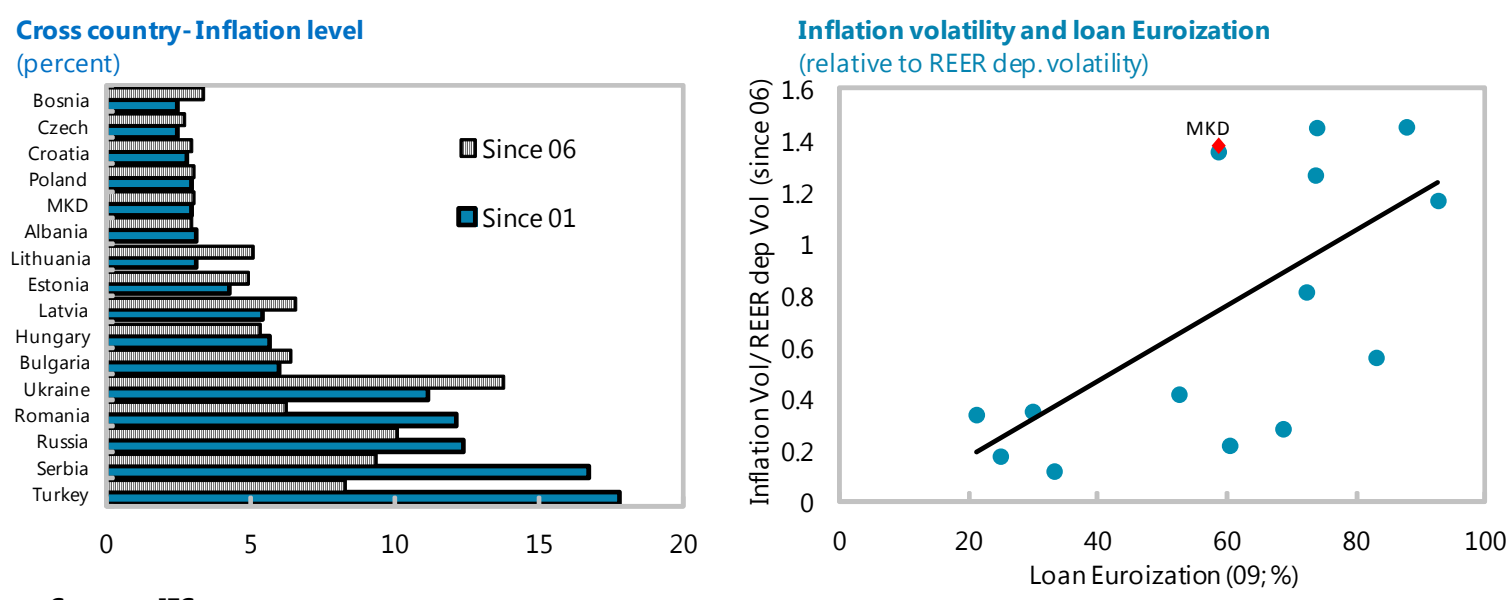

Source: IFS.

10. Expectations of inflation volatility and institutional credibility also play crucial roles. Expectations of inflation volatility may differ from observed inflation volatility, as people tend to have long memories of past hyperinflation episodes, even if the current regime has managed to reduce inflation levels and volatility significantly. In the case of Macedonia, though more than a decade has passed since the hyperinflation episode in 1993, there is evidence that people still see the euro as a better store of value (OeNB Euro Survey, 2007).

\section{The stability of the exchange rate peg is crucial for the health of the financial} system and borrowers might be counting on an implicit government guarantee.

Regulation in Macedonia requires that banks' net open FX position does not exceed 30 percent of their own funds. Therefore, there is no significant currency mismatches on the banks' balance sheets. However, there is significant indirect credit risk, as many borrowers of FX loans are not hedged. Loans to naturally hedged companies account for only 
9.9 percent of total FX and FX-indexed loans. In the tail risk event of a large depreciation, the consequences for the financial system would be so dramatic that borrowers may expect the government to take extraordinary measures to maintain the peg at all costs, or in the event of depreciation, to alleviate the costs of depreciation-related insolvencies.

\section{Borrower myopia does not seem to be a strong reason behind loan euroization.}

Under this hypothesis, borrowers prefer to borrow cheaper FX loans in spite of the higher currency risk. The explanation that borrowers might not understand, underestimate or excessively discount the risks associated with borrowing in foreign currency conflicts with the high degree of deposit euroization in Macedonia. In spite of the higher returns offered by local currency deposits, residents choose to keep a large share of their deposits in FX, showing an understanding of the currency risks.

\section{On the supply side, deposit euroization is prevalent, contributing to high loan}

euroization. It has been documented that banks' need to match the currency structure of their assets and liabilities plays a role behind FX lending. In the case of Macedonia, foreign currency funding from abroad is limited. However, deposit Euroization ranks amongst the highest in the region. In addition, FX deposits appear to be very sensitive to residents' perceptions of macroeconomic risk.

Figure 4. Funding sources currency denomination.
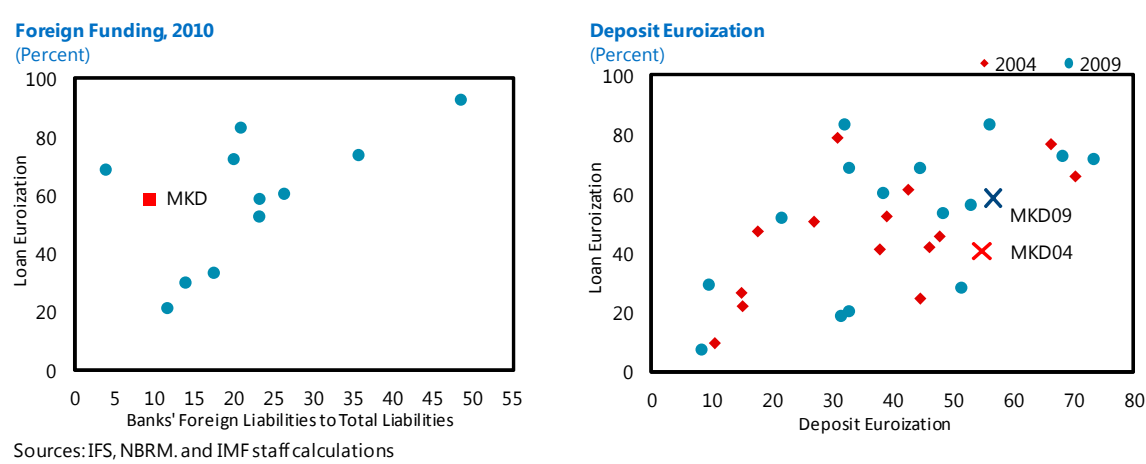

14. In Macedonia, the authorities have put in place several safeguards and incentives to reduce the risk of euroization and build buffers. These include differential reserve requirements, limits on net open FX positions, and prudential requirements that require banks to assess and control indirect FX risk (Box 1).

\section{Policy Implications for FYR Macedonia}

15. While de-euroization would bring benefits, these are more limited in a fixed exchange rate regime such as in Macedonia than in a more flexible regime. In general, the literature has identified the following main benefits of financial de-euroization:

- $\quad$ Avoiding loss of seigniorage. If there is a high degree of currency substitution (use of euro banknotes), then the loss of seigniorage could be large. Although data are not 
available on seigniorage, there is little evidence of significant currency substitution. Therefore, de-euroization is unlikely to affect seigniorage much.

- $\quad$ Improving the effectiveness of monetary policy. As monetary policy could have a direct impact only on the local currency rates, a high degree of euroization would

\section{Box 1. Regulation of FX-Induced Credit Risk in the NBRM's Supervisory Framework}

Macedonia has in place a number of prudential regulations that act as incentives against euroization, mitigate risks, or create buffers.

Differential reserve requirements. Reserve requirements are 10 percent on denar deposits, 13 percent on FX deposits, and 20 percent on FX-indexed deposits.

Net open FX position: A bank's aggregate net open FX position at the end of any business day should not exceed 30 per cent of the banks' own funds. The FX position includes both FX and FX-indexed assets and liabilities.

Capital adequacy: The additional capital requirements for currency risk are calculated by multiplying the sum of the absolute amount of the net position in gold and the bank's aggregate FX position, by $8 \%$.

Identification of unhedged FX borrowers: A bank should have a system to assess and monitor the compliance of a client's FX position. In particular, banks should:

- Monitor and assess the borrower's FX claims and liabilities structure by currency and maturity;

- $\quad$ Stress test the borrower's cash flows in terms of their capability to repay liabilities to the bank following a depreciation of denar against the currency in which the loan is denominated, or indexed, at least on an annual basis;

- $\quad$ Determine an adequate amount of collateral, in line with the assessment of the borrower's creditworthiness and its capacity to repay its debt following a depreciation of denar;

Determine a quantitative limit on the amount of each FX or FX-indexed loan to residents, as well as a quantitative limit on the share of the FX and/or FX-indexed credit exposure of residents in the bank's total credit exposure;

- $\quad$ Assess the influence of exchange rate fluctuations on the bank's loan portfolio, by stress tests or other types of simulation, at least once a year, if the bank's FX and FX-indexed loans to residents exceed 15 percent of its total credit to residents, net of the bank's FX deposits and the FX or FXindexed investments of securities issued by the Macedonian government.

A client is considered to have a hedged FX position if its expected FX inflows, FX and FX-indexed claims cover at least 80 percent of its total expected FX outflows, FX and FX-indexed liabilities.

Documentation of FX exposure: A Bank's credit file has to contain all relevant data available to the bank for determining a client's identity, creditworthiness, regularity of settling its liabilities and collateral quality, including approval and monitoring exposures which are part of the retail credit portfolio and analysis of the borrower's exposure to foreign exchange rate risk.

- $\quad$ limit the effectiveness of monetary policy transmission. However, given Macedonia's exchange rate regime (i.e., a peg to the euro), which has served Macedonia well in the 
last decade and has been seen as the most important policy anchor (not only for monetary policy, but also as a disciplining tool for fiscal policy), the amount of monetary policy autonomy is limited. ${ }^{4}$ Therefore, under the current exchange rate regime, there may not be much gain in this area even with zero degree of euroization.

16. Reducing balance sheet risks. This would be the main benefit of de-euroization in Macedonia. Direct or indirect currency exposure on banks' balance sheets renders the banking system vulnerable to large exchange rate movements. From an individual banker's perspective, this risk is small as Macedonia is firmly committed to maintaining the exchange rate peg, and even if devaluation happens in a tail risk event, the state is likely to provide support to the banks to contain losses. However, on an aggregate level, such balance sheet risks deprived Macedonia a "safety valve" - that is, to use exchange rate flexibility as a shock absorber in a tail risk scenario. Although such crisis scenario seems unlikely at this point, reducing balance sheet risks would allow the "safety valve" to be available.

\section{Cross-country experiences suggest that progress towards de-euroization will}

take time to achieve. A few lessons could be drawn from past successful cases of de-euroization:

- In general, countries that managed to de-euroize successfully tend to have flexible exchange rate regimes. Exchange rate volatility makes the foreign exchange risk more apparent, providing disincentive to euroization. Credible fixed exchange rate regimes, on the other hand, may be seen as an implicit guarantee and hence could encourage euroization. The four successful cases of de-euroization identified in Reinhart, Rogoff, and Savastano (2003) — Chile, Israel, Mexico, and Poland —all have flexible exchange rate regimes. ${ }^{5}$ Given Macedonia's strong commitment to the exchange rate peg, it could be more difficult to de-euroize rapidly. Macedonia's long-term commitment to join the EU and eventually the euro area adds credibility to the exchange rate regime and make a move towards more exchange rate flexibility less likely.

- De-euroization needs to be underpinned by macroeconomic stability, and supported by public debt management and development of domestic financial market. For example, Israel, Chile and Poland all started their de-euroization process by bringing down inflation, gradually stabilizing the economy, and liberalizing the financial sector and the capital account. Macedonia has been able to achieve macro stability under the exchange rate peg and prudent fiscal policy in recent years, and managed to weather the global crisis relatively well. Active public debt management and

\footnotetext{
${ }^{4}$ For detailed discussions on the effectiveness of monetary policy in Macedonia under the peg, see Selected Issues Paper "Monetary Policy in Macedonia", 2012.

${ }^{5}$ The successful cases are identified based on the following criteria: deposit euroization falls by at least 20 percentage points and remains below 20 percent.
} 
development of domestic financial market are important policies to support de-euroization. Issuing local currency-denominated public debt can de-euroize the government's balance sheet, lengthen the domestic currency yield curve and foster domestic debt market. Macedonia was making progress in this area until the global crisis, and then moved in the opposite direction by relying more on foreign-currency denominated public debt. ${ }^{6}$ Finally, developing a deep and liquid domestic financial market would increase the choice of local currency-denominated securities and may contribute to the decrease in FX-denominated assets (e.g., FX deposits). Encouraging the development of the domestic investor base, such as pension funds, would likely support demand for longer-term local currency instruments and markets.

- De-euroization could be a long process and may last after macro stability has been achieved. The public tends to have long memories of past crisis episodes, and hence may continue to regard local currency as more risky. Also as the public has become accustomed to using foreign currency in financial transactions and does not internalize the negative externality of using FX to the whole economy, de-euroization does not happen automatically even if successful macro stabilization has increased the attractiveness of the local currency. For example, Chile continued to experience indexation (to FX) even after it managed to stabilize the economy in the 1990s and later adopted inflation targeting and allowed the peso to float freely in 1999.

- Prudential regulation should remain in place to address euroization. This will help to ensure management of FX risks, provide buffers, and create soft incentives for de-euroization. Macedonia could also consider enhancing such prudential policies with measures taken by other countries, including (i) higher liquidity requirements on foreign currency deposits (Angola and Uruguay) or foreign currency loans (Croatia); (ii) higher capital and provisioning requirements on foreign currency loans, especially to unhedged borrowers (Angola, Honduras, and Vietnam); and (iii) lower loan-to-value ratio to improve buffers on foreign exchange denominated loans (Hungary).

\section{Conclusions}

18. This paper analyzes the main causes of euroization in Macedonia. High loan euroization in Macedonia appears to be driven by inflation volatility, including both current volatility and memories of past hyperinflation episode, low exchange rate volatility and potential implicit guarantees perceived under the exchange rate peg, together with larger demand and supply of euros as Macedonia becomes more integrated to the region in trade and financial flows.

\footnotetext{
${ }^{6}$ For assessment and recommendations on how to development domestic debt market, see Selected Issues Paper "Debt Market Development in FYR Macedonia", 2012.
} 
19. Even with incentives to de-euroize, Macedonia is likely to remain euroized for a long time. Both the literature and cross-country evidences suggest that it is difficult to reverse euroization, which is persistent even when macro stability has been well established. Moreover, there seems to be some regional pattern of euroization-emerging Europe has remained highly euroized in the last two decades, despite significant progress in achieving macro stability and efforts to de-euroize. This is likely related to the region's economic integration with the EU and aspirations eventually to join the euro area.

20. De-euroization is desirable to provide a safety valve for potential future risks, although the advantages are somewhat limited given the exchange rate peg. The main advantage of de-euroization in Macedonia is to reduce balance sheet risks that could make the banking system vulnerable to large exchange rate movement. De-euroization would allow the "safety valve" to work when circumstances warrant. Other benefits of de-euroization, such as avoiding loss of seigniorage and improving the effectiveness of monetary policy, are limited in Macedonia. In particular, under the peg, there is limited amount of monetary policy autonomy, and de-euroization would not help much on that front.

21. In staff's view, the best strategy is to provide incentives and a supportive macro-financial context for gradual reduction of euroization, through prudential policies and by maintaining macro stability and developing domestic debt markets. Macedonia has been implementing prudent macro policies and has achieved macro stability in the last decade, including during the global financial crisis. Maintaining such sound policies is a pre-requisite of de-euroization. Given that the exchange rate peg has limited the scope of monetary policy to respond to inflation, fiscal policy could play a larger role, including by improving public debt management and relying more on longer term denar loans. This would be an important step to de-euroize the balance sheet of the public sector and to lengthen the yield curve, fostering the development of domestic debt market. A deep and liquid domestic capital market could provide more investment opportunities in denar as a substitute for FX-denominated assets, and hence help de-euroization. 


\section{REFERENCES}

Baliño T., Bennett A., and Borensztein E., "Monetary Policy in Dollarized Economies, IMF Occasional Paper No. 171, 1999.

Basso H., Calvo-Gonzales O. and Jurgilas M., "Financial dollarization-The role of banks and interest rates”, European Central Bank Working paper 748, May 2007.

Brown M. and De Haas R., "Foreign currency lending in emerging Europe: Bank-level evidence”, EBRD working paper 122, 2010.

Brown M., Onega S. and Yesin P., "Foreign currency borrowing by small firms", CEPR Discussion paper 7540, 2009.

Brown M., Onega S. and Yesin P., "Foreign currencyloans - Demand or Supply driven?", CEPR Discussion paper 7952, 2010.

Chaillouk A., Ohnsorge F. and Vavra D., "Euroisation in Serbia", European Bank for Reconstruction and Development, WP 120, October 2010.

EBRD Transition Report 2010, Chapter 3.

Kokenyne A., Ley J. and Veyrune R., "Dedollarization”, IMF Working Paper, WP/10/199, 2010.

Luca A. and Petrova I., "What drives credit dollarization in transition economies?", Journal of Banking and Finance, August 2007.

Reinhart C., Rogoff R., and Savastano M., “Addicted to Dollars”, NBER Working Paper 10015, 2003.

Rosenberg C. and Tirpak M., "Determinants of foreign currency borrowing in the new member states of the EU", IMF working paper 08/173, July 20008.

Zettlemeyer J., Nagy P. and Jeffrey S., "Addressing private sector currency mismatches in emerging Europe”, European Bank for Reconstruction and Development, WP 115, June 2010. 


\section{Autonomy of Monetary Policy under a Peg: The CaSe of FYR Macedonia ${ }^{1}$}

Imperfect capital mobility provides monetary policy under the exchange rate peg in Macedonia with a certain degree of autonomy in the short-term. However, the policy rate spread over Euro area rates has historically tracked measures of risk premium, which suggests the latitude for maneuver is limited. We also present a stylized model of an economy with an exchange rate peg and a partial autonomy in its monetary policy, and show that under these circumstances, interest rate volatility is lower compared to a case where monetary policy does not pay attention to reserve accumulation and is set through a traditional Taylor rule. Overall, we conclude that it is important that NBRM interest rate policies continue to be driven foremost by the need to preserve confidence in the peg by holding adequate international reserves.

\section{A. Introduction}

1. Macedonia has a de facto fixed exchange rate regime. Price stability is the primary objective of the NBRM specified by law. The maintenance of denar exchange rate stability serves as an intermediate target for achieving price stability. The fixed exchange rate regime is implemented by the NBRM with standing offers to buy and sell FX with the main banks at a small window around the target. The peg has been against the Euro since January 2002 (before, since 1995, it was pegged against the Deutsch Mark). Sometimes direct forex interventions are supported by sharp changes in the policy interest rate "to preserve exchange rate bands as an intermediate target” (e.g. during speculative attacks).

\section{Under perfect capital mobility and a fixed exchange rate regime, monetary} policy is not autonomous. An attempt to reduce domestic interest rates below foreign interest rates (plus a risk premium) would translate into substitution of national for foreign currency. The higher demand for FX would put pressure on the local currency, but the central bank would be committed to intervene and therefore lose reserves. Persistent loose policies would quickly deplete reserves and undermine the peg.

3. In Macedonia, the degree of integration with international financial markets is limited, which suggests that the "impossible trinity" might not fully hold. Imperfect capital mobility weakens the link between monetary policy and reserves and some degree of monetary autonomy is gained. Under such conditions, monetary policy enjoys certain room to react to domestic shocks, i.e., the domestic policy rate is not exclusively determined by the movements of the ECB policy rate.

4. The interest rate on the central bank bills is the key interest rate, which determines the monetary policy stance (i.e., policy rate). To decide monetary policy the

\footnotetext{
${ }^{1}$ Prepared by Nicolas Arregui, narregui@imf.org and Maral Shamloo, mshamloo@imf.org.
} 
NBRM assesses current and future macroeconomic developments that primarily influence the denar/ euro exchange rate and the inflation rate, as the intermediate and ultimate goals of monetary policy. Additionally, the NBRM takes into account the need to maintain financial stability and the expected effect of monetary policy on future economic growth developments.

5. This paper studies the role of monetary policy in Macedonia. Firstly, we characterize empirically the behavior of the policy rate during the last decade. We show that while imperfect capital mobility provides monetary policy with a degree of autonomy in the short-term, this appears limited, as the policy rate spread has historically tracked measures of risk premium. Secondly, we introduce a semi-stylized model of semi-autonomous monetary policy.

\section{B. The Policy Rate in 2000-2011}

\section{The Macedonian de facto exchange rate peg has been challenged several times}

during the last ten years. A variety of shocks (security crisis, monetary policy, speculation, external shocks) have resulted in large drops in the level and import coverage of central bank's foreign assets that lasted for extended periods of time. Table 1 summarizes five stress periods that averaged drops in foreign assets by 17 percent and lasted between 6 and 14 months.

Table 1. MKD: Crisis periods in NBRM FA

\begin{tabular}{cccccc}
\hline Crisis Period & $\begin{array}{c}\text { Duration } \\
\text { months }\end{array}$ & \multicolumn{2}{c}{ Cumulative loss in Reserves } & \multicolumn{2}{c}{ Months of imports } \\
& (mn dols) & (percent*) & at start & at end \\
\hline Feb 01-Sep 01 & 8 & 253.0 & 24.3 & 6.4 & 4.8 \\
May 02 - Mar 03 & 11 & 232.7 & 28.2 & 4.6 & 3.4 \\
Oct 03 - Nov 04 & 14 & 9.0 & 1.0 & 3.8 & 3.2 \\
Nov 07 -Apr 08 & 6 & 95.8 & 4.3 & 4.1 & 3.9 \\
Oct 08-May 09 & 8 & 732.5 & 30.1 & 4.3 & 3.2 \\
\hline
\end{tabular}

* of FA on month prior to crisis

Source: NBRM.

\section{The most severe crises in the last decade were aggravated by deposit}

withdrawals and increased euroization. Private sector deposits dropped by 14 percent in the security crisis of 2001 and by 8 percent in 2008-9 as the global crisis hit. In both episodes the drop in corporate deposits was steeper and more persistent than household deposits. Additionally, by the end of both crisis periods the degree of household euroization had increased significantly. 
Figure 1. MKD: Euroization during stress times (2000-1 and 2008-9)
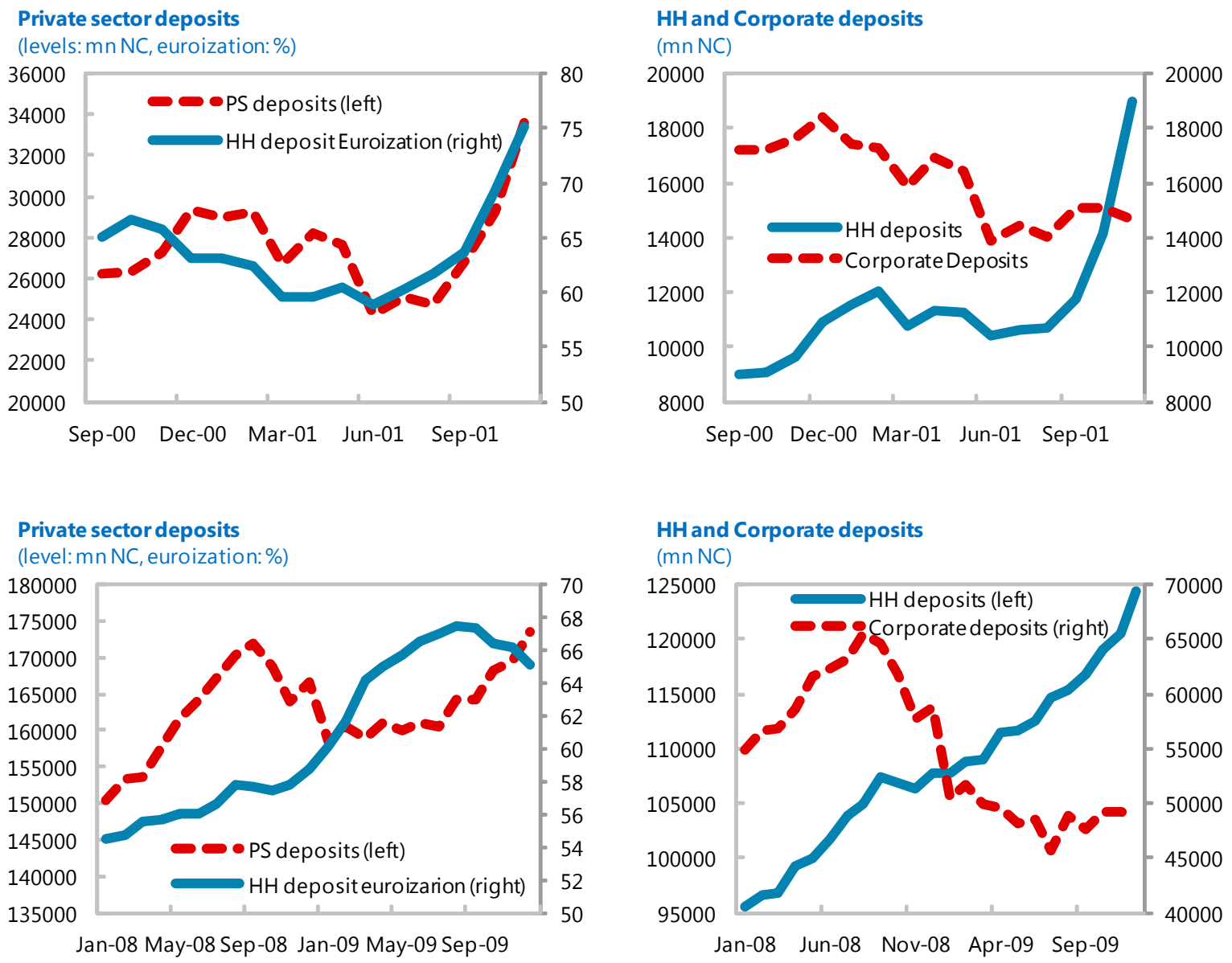

Source: NBRM.

8. Monetary policy successfully defended the peg during stress times. Figure 2

shows the response of the policy rate during the episodes of stress in reserves. In terms of the "Framework for Assessing Monetary Policy in Macedonia" in Gottlieb 2010, the NBRM has established its commitment to the peg by timely tightening the policy rate in every occasion that reserves were "low and falling". Based on past NBRM policy reactions, it should be noted that:

- Both levels and changes matter. A large inflow of foreign reserves from the privatization of the telecommunications company in January 2001 kept foreign assets at comfortable levels even after the large losses in reserves (24.3\%) during the security crisis in 2001 . The NBRM strongly reacted by more than doubling the policy rate to 20 percent.

- Imports coverage by Foreign Assets matters. During the stress period in 2003-4, the drop in reserves was only minor (1\%) but the coverage of imports of goods and services collapsed to the historical minimum of 3.2 months. The NBRM raised the 
policy rate and a program was agreed with the IMF aimed to strengthen the exchange rate peg by increasing foreign exchange reserves. The program relied on proceeds from two large privatizations to build up reserve cover in the first two years and on sound macroeconomic policies to maintain reserve cover thereafter.

\section{Figure 2. MKD: Policy rate and Foreign Assets}

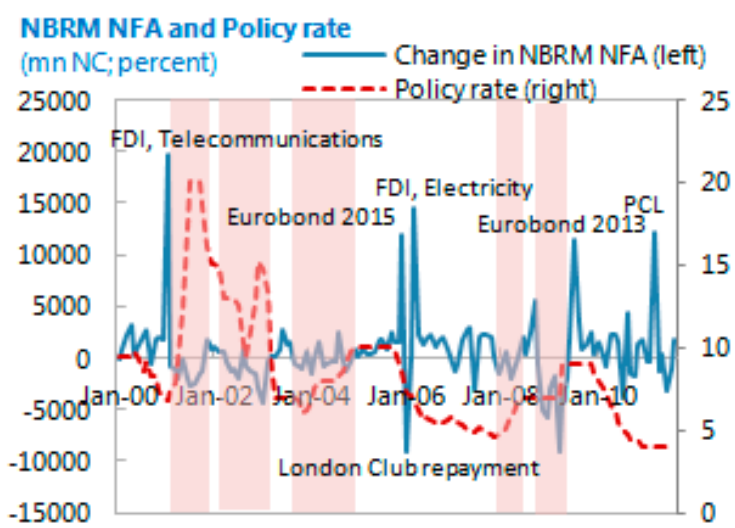

Sources: NBRM and IMF staff calculations

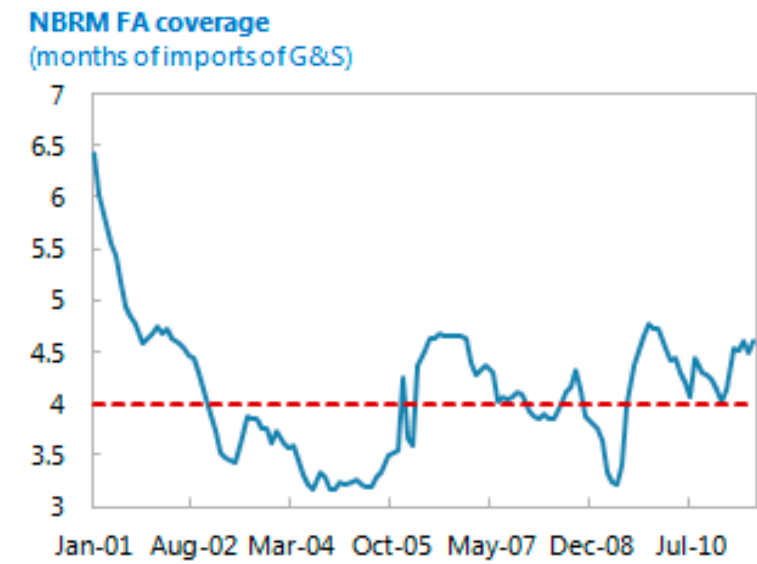

9. During stress times, the NBRM has usually complemented the policy rate hikes with a variety of other policy responses. In 2001 the central bank increased reserve requirements, imposed a temporary restriction on FX sales to big firms and bureaus, and shortened the period for surrendering export proceeds from 180 to 30 days. In 2003-4 reserve requirements were introduced on FX deposits and CB-bills auctions shifted to volume tender to better signal the monetary policy stance. In 2008 the capital adequacy requirements for overdraft and credit card loans were increased and the base for reserve requirements was broadened. In 2009 the NBRM introduced liquidity ratios requirements and increased the reserve requirements for FX and FX indexed deposits.

10. In addition to its commitment to the exchange rate peg, the NBRM has also used monetary policy in response to inflationary concerns. The central bank tightened monetary policy during the first half of 2008 when international reserves were relatively stable and import coverage was at broadly adequate levels. The explicit rationale behind the tightening was the idea that the economy was overheating, with high inflation, high credit growth and current account deterioration.

\section{The Degree of Monetary Autonomy}

\section{While imperfect capital mobility provides monetary policy with a degree of} autonomy in the short-term, this appears limited. In the case of a peg without monetary autonomy, the monetary policy stance is determined by the uncovered interest parity condition (UIP), which establishes the domestic interest rate equal to the foreign interest rate plus a risk premium $\left(i=i^{*}+\right.$ premium). Deviations from UIP would be an indication of monetary autonomy, but the risk premium is not directly observable. We use three proxies 
for the risk premium term: banks deposits and loans currency spreads and household deposit euroization. Currency spreads are expected to correlate with risk premium. The use of deposit euroization as a measure of risk premium is motivated by the idea that "Our experience so far has shown that the least uncertainty and suspicion about FX stability causes the percentage of euroization in deposits to immediately increase..." (Dimitar Bogov, inauguration speech as NBRM governor, 2010).

12. The policy rate spread has historically tracked closely measures of risk premium (Figure. 3). The commitment to the peg has driven the monetary policy stance over the last decade. Even if the NBRM may have some degree of independence in the magnitude or timing of the policy rate response, the figures suggests that there was limited scope for significant deviations from UIP. It is important that the NBRM continues with its track record of timely monetary responses based on the permanent monitoring of reserve adequacy measures, balance of payments dynamics, credit growth rates, trends in the ratio of euro-denominated to denar deposits, and Eurozone interest rates.

Figure 3. MKD: Policy rate and risk measures

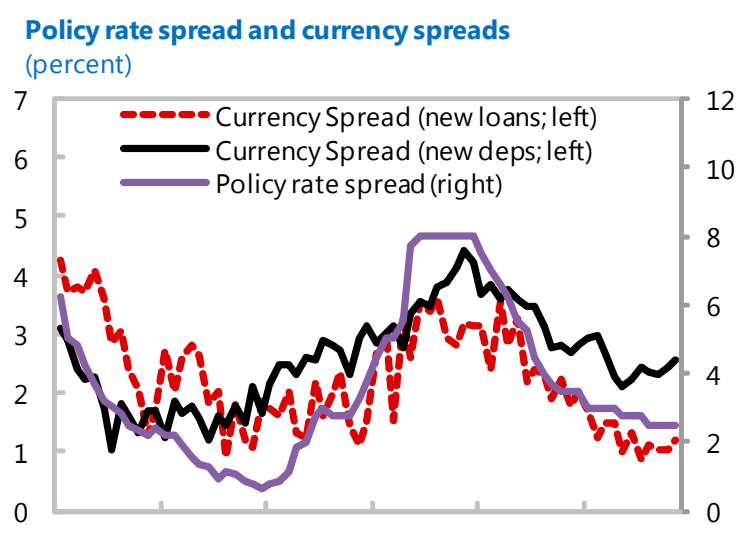

Dec-05 Dec-06 Dec-07 Dec-08 Dec-09 Dec-10

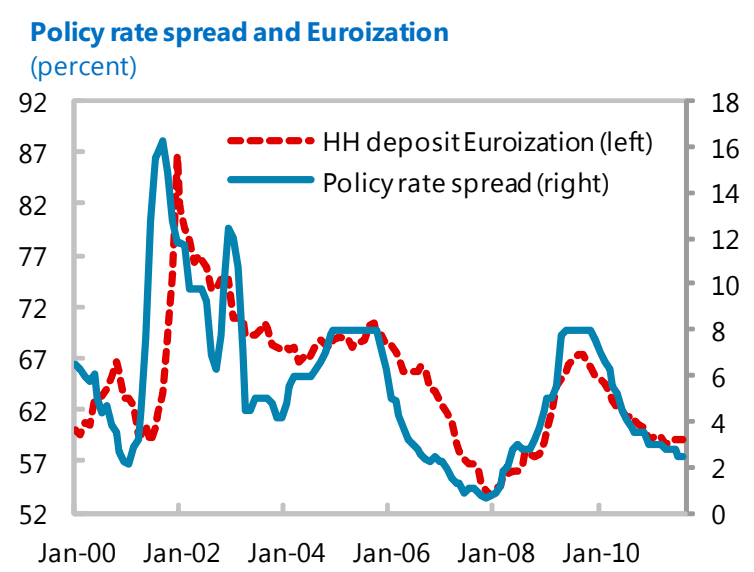

Sources: NBRM and ECB.

\section{A Model of Semi-Autonomous Monetary Policy}

13. The evidence above shows that the monetary authority in a country with a pegged exchange rate regime, but with imperfect capital mobility, might have some room to practice independent monetary policy. In this section, we present a model which features the central bank's dual objective of defending the peg and affecting inflation and output gap outcomes when the exchange rate is not under pressure.

The model assumes that there is some monetary autonomy, i.e., domestic interest rates can differ from UIP. Furthermore, the monetary authority cares about deviations of inflation and output gap from a target. To the extent that the constraint from the exchange rate regime is 
not binding, the monetary authority would like to set interest rates like a central bank with the dual mandate of inflation and output gap.

Inflation and output gap follow the standard new-Keynesian dynamics:

$$
\begin{gathered}
\pi_{t}=\lambda x_{t}+\varepsilon_{t} \\
x_{t}=-\psi\left[i_{t}^{\text {policy }}-E_{t} \pi_{t+1}\right]+v_{t}
\end{gathered}
$$

$\pi_{t}$ is price level inflation, $x_{t}$ is output gap defined as deviations of output from its long-run (or flexible-price) level, and $E_{t}$ is the expectations operator. The first relationship is often referred to as the New-Keynesian Phillips curve, since, in the spirit of the traditional Phillips curve, suggests a trade-off between economic activity and inflation rate. Unlike the traditional Phillips curve however, this is a micro-founded relationship, derived from the profit maximization conditions of the firms. The second relationship is often referred to as the IS or aggregate demand curve, and it describes the relationship between economic activity and real interest rates.

In the absence of any pressure on exchange rate, the central bank would set interest rates according to a Taylor rule:

$$
i_{t}^{T}=\alpha\left(\pi_{t}-\pi^{T}\right)+b x_{t}
$$

where $\pi^{T}$ is an implicit or explicit inflation target. However, deviations from the UIP affect reserve accumulation or decumulation.

where $r_{t}$ is log of reserves at time $t$.

$$
\Delta r_{t}=i_{t}^{\text {policy }}-i^{*}+\eta_{t}
$$

We assume that the central bank tries to set policy rate $i_{t}^{\text {policy }}$ as close to the Taylor rule interest rates $i_{t}^{T}$ as possible, while keeping the level of $r$ above a threshold $\underline{r}$.

The minimization problem of the $\mathrm{CB}$, thus, becomes:

Such that

$$
\min _{\mathrm{i}_{\mathrm{t}}^{\mathrm{U}}} \sum_{t=0}\left[\left(i_{t}^{\text {policy }}-i_{t}^{T}\right)^{2}+C\left(r_{t}, \underline{r}, \Delta r_{t}\right)\right]
$$

$$
\begin{gathered}
\pi_{t}=\lambda x_{t}+\varepsilon_{t} \\
x_{t}=-\psi\left[i_{t}^{\text {policy }}-E_{t} \pi_{t+1}\right]+\varepsilon_{t}
\end{gathered}
$$

where $C\left(r_{t}, \underline{r}, \Delta r_{t}\right)$ is a cost function. We have not specified the cost function here. But some desirable properties are as follows. First, the cost function needs to be asymmetric, i.e., there is no cost of higher reserves. ${ }^{2}$ Second, as we have indicated, the cost function can depend on both the level and the rate of change of reserves. Finally, the cost should be very large as $r$ approaches $\underline{r}$.

\footnotetext{
${ }^{2}$ Costly reserve accumulation could be modeled. Such costs would arise from an interest rate differential and not from a stability point of view.
} 
Replacing inflation from the Phillips curve into the IS curve, we obtain

$$
x_{t}=-\psi \sum_{t=0}(\psi \lambda)^{j} E_{t} i_{t+j}^{\text {policy }}+u_{t}
$$

Note that output gap (and thus inflation) is a function of not only monetary policy today, but the path of monetary policy in the future, since expectations about the policy rate in the future appear on the right hand side. This standard feature of new-Keynesian models implies that the monetary authority behaving optimally would not be myopic and would take into account the probability of hitting constraints in the future, in setting the policy rate today. In this particular case, the monetary authority internalizes that lowering interest rates today, increases the probability of approaching the minimum reserve level, or an increase in the cost function in the future.

Dynamics in the reserves are determined by how far from UIP interest rates we are. Higher interest rates imply reserve accumulation, whereas lower interest rates imply reserve decumulation.

It is important to note that the reserve accumulation equation is not a reaction of the policy rate to reserves, but a statement of how reserve accumulation can be affected by the differential interest rates at home and abroad. In other words, it is a law of motion. On the other hand, policy reaction to reserve levels is defined implicitly by minimization problem.

\section{A Simplified Model}

The problem, as presented above has no analytical solution. A non-linear constraint on reserves makes the problem non-convex, and thus impossible to linearize without resorting to numerical methods. Thus, we will present a simplified example to which an analytical solution exists. We simplify the general framework above along three dimensions:

First, we cut the feedback from interest rates to inflation and output gap. In effect, we assume that inflation and output gap are exogenous. Second, we eliminate the infinite horizon maximization problem. The central bank becomes myopic, and only cares about the constraint binding today, as opposed to the probability of it binding in the future. Finally, we present a reduced form of the cost function, by assuming a weight function on reserve and inflation components.

Assume that interest rates are driven by UIP, but inflation and output gap evolution can matter for interest rates too.

$$
i_{t}=i^{*}+i_{s s}^{\text {prem }}+\left(1-\theta_{t}\right) *\left(-\Delta r e s_{-} g a p_{t}\right)+\theta_{t}\left[\alpha\left(\pi_{t}-\pi^{T}\right)+b x_{t}\right]+\varepsilon_{t}
$$

The weight on reserve gap depends on how far reserves are from a minimum level.

$\theta_{t}=\left\{\begin{array}{cc}1, & \text { if res_gap }>0 \\ \frac{1+r e s_{-} g a p_{t}-\underline{r}}{\log (1-\underline{r})} & \text { if } \underline{\text { gap }}<\text { res_gap }_{t}<0 \\ 0, & \text { if } r e s_{-} g a p_{t}<\underline{\text { gap }}\end{array}\right.$ 
In other words, developments in inflation and output matter to the extent that reserves are above a certain level. The law of motion for reserves is as before. Figure (4) shows the weight function on the "Taylor rule" component, as a function of reserve gap.

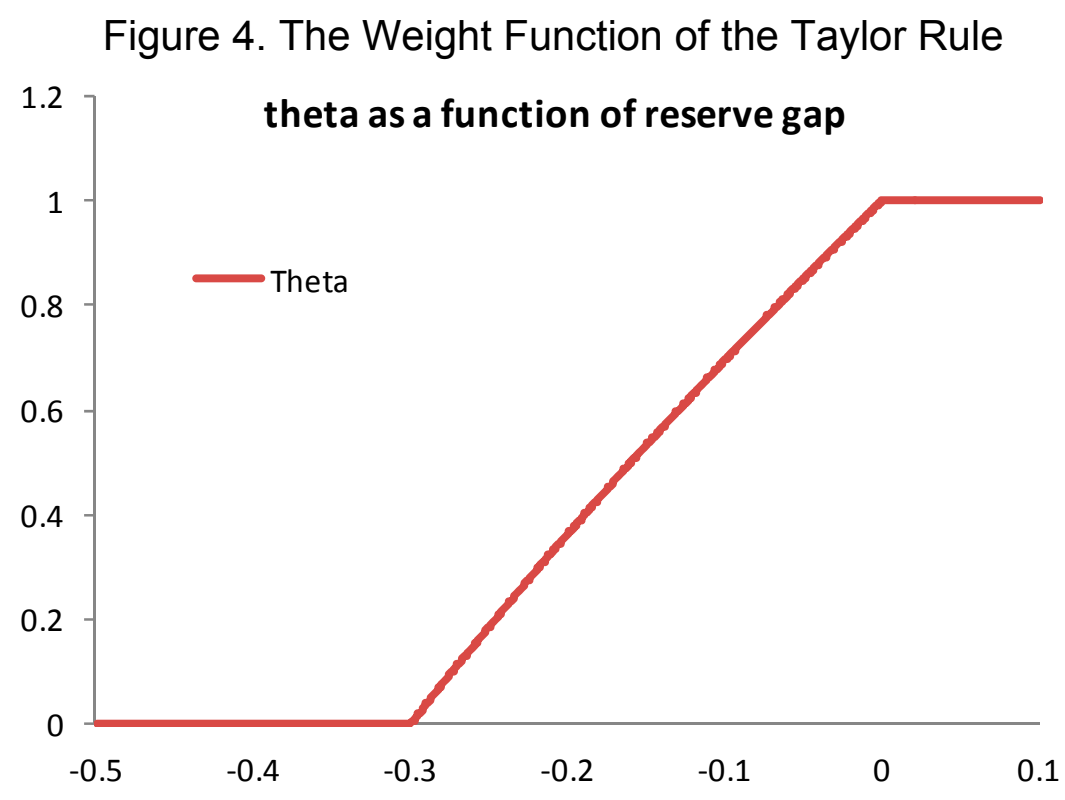

The y-axis shows the weight function, or $\theta_{t}$, which varies between 0 and 1 . The x-axis shows the reserve-gaps, in log-differences. Thus, we have calibrated the model such that the weight on the Taylor rule component becomes zero, if reserves are 30 percent below the reserve target. This calibration was loosely based on the empirical fact that the NBRM has reacted sharply with interest rates whenever reserves dropped by about 30 percent within an episode of reserve loss.

Under such a rule, the constrained and unconstrained interest rates deviate from each other. Inflation and output matter for interest rates if you have sufficient amount of reserves. An unconstrained interest rate rule is defined as $\theta=1$, or in other words, when reserves are high enough.

The central bank responds to a (positive) inflation shock or (negative) output gap shock by raising the rates. However, interest rates are set with attention to reserve accumulation. The policy response to reserve decumulation would be raising the rates. The importance of changes in reserves depends on the level of reserves. Reserves evolution depends on deviation of interest rates from UIP, similar to before.

Figure (5) shows a simulation of this simplified model in response to random shocks to reserves. Note that interest rates can be capped from below and from above. The intuition is as follows: assume that the reserve gap is negative implying $\theta<1$. In this case, if reserves are falling, a negative output gap shock (or a negative inflation shock) would imply a lower interest rate cut than under Taylor rule (implying a floor on the policy rate, or "capping from below"). The opposite is also true: if reserves are accumulating fast, the response to a positive inflation shock will be more muted than under the Taylor rule, i.e., a smaller increase in policy 
rates than would have occurred otherwise (implying a ceiling on the policy rate, or "capping from above").

This feature implies a lower volatility of interest rates compared to the unconstrained case.

Furthermore, the response to inflation shock might be muted because of reserve accumulation or decumulation. Note that there is no forward looking behavior in this example. A forward looking central bank would try to avoid hitting the lower bound in advance.

Figure 5. Constrained and Unconstrained Interest Rates in a Model of Monetary Policy
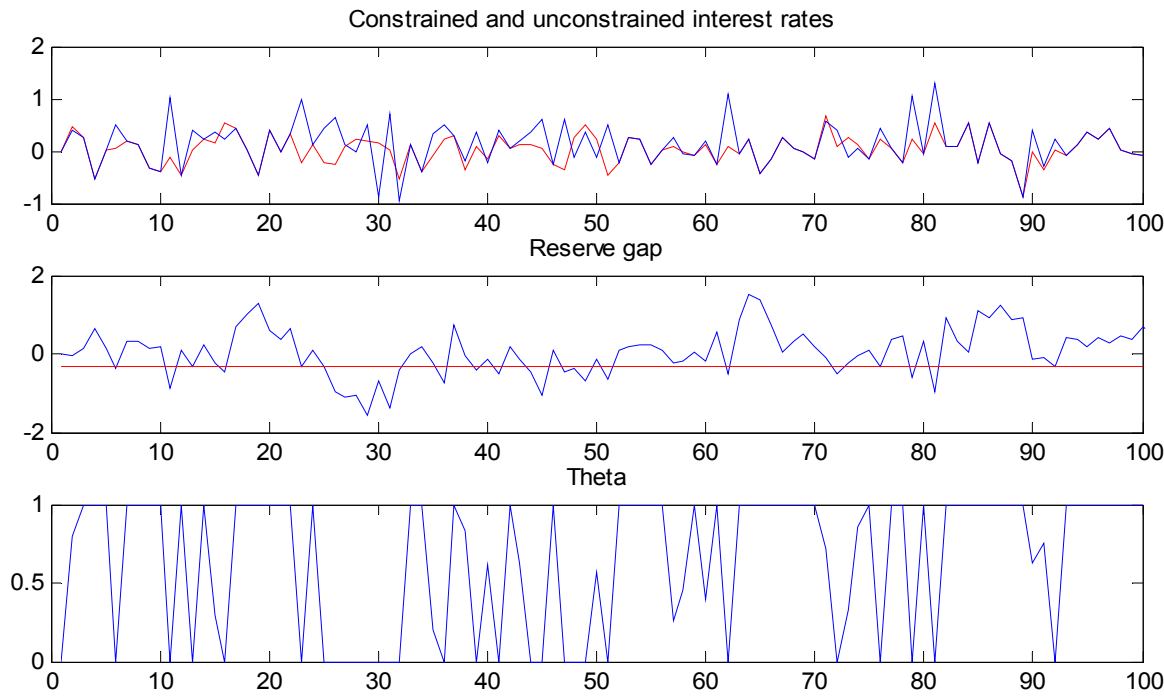

\section{E. Conclusions}

\section{In this paper we discuss the nature of monetary policy in a Macedonia where} despite an exchange rate peg, due to imperfect capital mobility there exists some degree of autonomy in the conduct of monetary policy in the short run. We document the episodes in which the NBRM seems to have had more latitude in setting policy rates, and the episodes in which monetary policy were driven mainly with the aim of maintaining reserves. We conclude that the latitude for maneuver is limited as the policy rate spread over Euro area rates has historically tracked measures of risk premium. Furthermore, we present a stylized model of an economy with an exchange rate peg and a partial autonomy in its monetary policy, and show that under these circumstances, interest rate volatility is lower compared to a case where monetary policy does not pay attention to reserve accumulation and is set through a traditional Taylor rule. Thus, the main conclusions of the paper can be summarized as follows: First, it is important that NBRM interest rate policies continue to be driven foremost by the need to preserve confidence in the peg by holding adequate international reserves. Second, policy rate volatility in response to supply and demand shocks is limited in a country with an exchange rate peg compared to a country with similar shocks but a floating exchange rate. 